\title{
Iowa University Towns and the Twenty-sixth Amendment: The First Test of the Newly Enfranchised Student Vote in 1971
}

\author{
Clyde Brown and Gayle K. Pluta Brown
}

AT THE END OF JUNE 1971 the Twenty-sixth Amendment became part of the U.S. Constitution. It gave 18- to 20-year-olds, including 160,000 Iowans, the right to vote in federal, state, and local elections. ${ }^{1}$ The amendment came at the end of a controversial decade of student activism, much of it aimed against the war in Vietnam. By lowering the voting age to 18, the amendment put to rest an issue that had been around since the nation's founding. This is the story of what happened when 18- to 20-year-olds were granted the franchise in the three Iowa cities that are home to the state's public universities - the University of Iowa (UI) in Iowa City, Iowa State University (ISU) in Ames, and the University of Northern Iowa (UNI) in Cedar Falls. The

Grants from the State Historical Society of Iowa and Miami University supported the research leading to this article. We thank the staffs of Special Collections and University Archives at Iowa State University, University of Iowa, and University of Northern Iowa for their assistance. We also appreciate the suggestions of three anonymous reviewers and the editor.

1. Estimate by Iowa Secretary of State Melvin D. Synhorst, cited in Cedar Falls Record, 10/3/1970. See also table in New York Times, 7/1/1971, 43.

THE ANNALS OF IOWA 68 (Fall 2009). (C) The State Historical Society of Iowa, 2009. 
first real opportunity for young Iowans to exercise their new right to vote came in the November 1971 local elections. ${ }^{2}$

In the three university towns, student candidates or the candidates they supported met with varying degrees of success. In Ames, anger over treatment of student protesters during antiwar demonstrations in May 1970 fueled activists' efforts to register their fellow students and get them to the polls to ensure victory for the activists' slate of candidates. In Cedar Falls, where the antiwar movement was small and not confrontational, UNI graduate student Jon Crews was elected mayor. And in Iowa City, where antiwar protests were frequently disruptive and sometimes violent, none of the five student candidates survived the primary, but one student-endorsed candidate won in the general election. The degree of students' electoral success in each community was the result of the interplay of several factors, including local issues and perceived grievances, the extent of organized student involvement, the number of candidates splitting the student vote, and local election rules.

DURING THE 1960s, colleges and universities throughout the United States coped with increasing enrollments and an increasingly restive student body. Students called for changes in campus rules governing student behavior such as dormitory curfews. They demanded a more relevant curriculum and pressed for the right to evaluate instructors. The civil rights movement came to campus as African Americans called for increases in the number of minority students and faculty and lobbied for the establishment of African American Studies programs and student centers. Feminists did the same, asking for more women faculty to be hired and for Women's Studies programs and women's centers on campus. By the end of the decade, homosexuals were coming together in their own gay rights movement. And widespread concern over air and water pollution and wildlife extinction led

2. School board elections took place in communities throughout Iowa on September 13, 1971. The deadline to register to vote for those elections was September 3, four days before fall classes began at ISU and ten days before they began at UI and UNI. As a result, many students would not have returned to Ames, Iowa City, and Cedar Falls in time to register to vote in the school board election; others would not have met the voter registration residency requirement. 
to the establishment of an environmental movement. But it was opposition to the Vietnam War that engaged the largest number of students, and the antiwar protester became the symbol of 1960 s student activism in the popular mind. ${ }^{3}$

Iowa's three public universities were not exempt from the upheaval that hit college and university campuses in the 1960s. Violent antiwar protests at the University of Iowa led to arson, vandalism on and off campus, attempts to block traffic on city streets and highways, and battles with counterdemonstrators. Because of the student outbursts, city and university officials brought outside law enforcement officers to Iowa City to supplement local and university police in November 1967, May 1970, and May 1971. ${ }^{4}$ Nonviolence prevailed at ISU's antiwar rallies and marches, with none of the destructive behavior seen at UI. Hundreds of UI students were arrested at protests over the years, but at ISU fewer than 50 went to jail, all in connection with two sit-ins in May 1970 protesting the Cambodian invasion. ${ }^{5}$ UNI experienced antiwar activities, too, but the bitterest Vietnam War-related controversy involved not mass protests, but a single individual. In an October 1967 campus newspaper article, English instructor Edward Hoffmans called on students to resist the draft. What became known as the "Hoffmans affair" would lead to accusations of press censorship, a spirited defense of academic freedom, and, ultimately, the firing of Hoffmans for alleged

3. For the 1960s generally, see David R. Farmer, The Age of Great Dreams: America in the 1960s (New York, 1994); William L. O'Neill, Coming Apart: An Informal History of America in the 1960s (Chicago, 1971); and David Steigerwald, The Sixties and the End of Modern America (New York, 1995). Kenneth J. Heineman, Put Your Bodies upon the Wheels (Chicago, 2001), provides an overview of the student movement in the 1960s. Student activism was not confined to colleges and universities; it was evident in secondary schools, even in Iowa. See John W. Johnson, The Struggle for Student Rights: Tinker v. Des Moines and the 1960s (Lawrence, KS, 1997) for an account of an important U.S. Supreme Court case that affirmed students' rights to symbolic speech.

4. Stow Persons, The University of Iowa in the Twentieth Century: An Institutional History (Iowa City, 1990), 194-95, 199-200.

5. Clyde Brown and Gayle K. Pluta Brown, "Moo U and the Cambodian Invasion: Nonviolent Anti-Vietnam War Protest at Iowa State University," in The Vietnam War on Campus: Other Voices, More Distant Drums, ed. Marc Jason Gilbert (Westport, CT, 2001), 119-41; and Clyde Brown and Erik L. Lewis, "Protesting the Invasion of Cambodia: A Case Study of Crowd Behavior and Demonstration Leadership," Polity 30 (1998), 645-65. 
poor performance in the classroom, not for his antiwar activities as conservative politicians and journalists had demanded. ${ }^{6}$ At all three schools, the Vietnam Moratorium in fall 1969 and demonstrations following the Cambodian invasion and the student killings at Kent State University and Jackson State College in May 1970 brought out the largest number of student protesters.

In addition to protest, young people in the 1960s, many energized by the election and inaugural address of President John F. Kennedy, became active in electoral politics. Not surprisingly, as student opposition to the Vietnam War increased, students gave their allegiance to candidates pledged to ending the war, most notably the 1968 presidential campaigns of Senators Eugene McCarthy (D-Minnesota) and Robert Kennedy (D-New York). McCarthy's campaign, dubbed the "children's crusade," attracted legions of young people even though many volunteers and staffers were not old enough to vote.

THE POLITICAL UPHEAVAL of the 1960s, including the bitter controversy over U.S. involvement in Vietnam, led to the revival of efforts to lower the voting age to $18 .^{7}$ Proposals to lower the voting age were put forward "during or after every major war" as far back as the American Revolution by proponents who argued that if young soldiers were old enough to fight, they were old enough to vote. The Vietnam War provided a new twist on that argument. ${ }^{8}$ Far from simply rewarding the sacrifices of mili-

6. William C. Lang and Daryl Pendergraft, A Century of Leadership and Service: A Centennial History of the University of Northern Iowa, 2 vols. (Cedar Falls, 1995), 2:282-94.

7. For information on why the voting age was set at 21, see Richard J. Cretan, "Twenty-sixth Amendment," in Constitutional Amendments: 1789 to the Present, ed. Kris E. Palmer (Farmington Hills, MI, 2000), 567; Wendell W. Cultice, Youth's Battle for the Ballot: A History of Voting Age in America (Westport, CT, 1992), 2; and Senate Subcommittee on Constitutional Amendments of the Committee on the Judiciary, Lowering the Voting Age to 18: Hearings Relating to Proposed Constitutional Amendments Lowering the Voting Age to 18, 91st Cong., 2nd sess., 1970, 157.

8. Alexander Keyssar, The Right to Vote: The Contested History of Democracy in the United States (New York, 2000), 277; David E. Kyvig, Explicit and Authentic Acts: Amending the U.S. Constitution, 1776-1995 (Lawrence, KS, 1996), 363-65; Richard B. Bernstein with Jerome Agel, Amending America: If We Love the Constitu- 
tary men aged 18 through 20, the franchise would give youthful opponents of the war the opportunity to vote for politicians who wanted to end the fighting. Despite public opinion polls during the 1960s indicating increasing support for a lower voting age, at the end of the decade only Georgia, Kentucky, Alaska, and Hawaii permitted those younger than 21 to vote.

Proposals to allow 18- to 20-year-olds to vote moved forward in Iowa and other states in $1970 .{ }^{10}$ That year the Iowa legislature took the first step toward amending the state constitution to lower the voting age to 19. To finalize the measure, the 1971 legislature and Iowa voters would have to give their approval. In the end, passage of the Twenty-sixth Amendment to the U.S. Constitution made amending the state constitution unnecessary.

At the start of 1970, passage of a federal amendment lowering the voting age did not seem imminent. Some members of Congress, such as Senator Jennings Randolph (D-West Virginia), had been pushing for an amendment since the 1940s without success. In early summer 1970, however, Senate Majority Leader Mike Mansfield (D-Montana) and Senators Edward Kennedy (D-Massachusetts) and Warren Magnuson (D-Washington) decided to bypass the cumbersome amendment process. They added a provision to enfranchise 18- to 20-year-olds to the renewal of the 1965 Voting Rights Act despite warnings that the tactic would not pass constitutional muster. ${ }^{11}$ Several states, in-

tion So Much, Why Do We Keep Trying to Change It? (New York, 1993), 136-38; Cultice, Youth's Battle, 4-18.

9. Close Up Foundation, The 26th Amendment: Pathways to Participation (Alexandria, VA, 2001), 2; Cultice, Youth's Battle, 24-27, 55-56, 58-60, 144-58, 196.

10. Legislation to lower the voting age had been introduced in the Iowa General Assembly every year since 1945, but it languished in committee. See Cultice, Youth's Battle, 31. In 1970 measures to lower the voting age were successful in Massachusetts, Minnesota, and Montana, where the voting age was lowered to 19; in Maine and Nebraska, where it was dropped from 21 to 20; and in Alaska, where it went from 19 to 18. Proposals to lower the voting age failed that same year in Colorado, Connecticut, Florida, Hawaii, Michigan, New Jersey, South Dakota, Washington, and Wyoming. See Cultice, Youth's Battle, 144-59.

11. Keyssar, Right to Vote, 280; Cultice, Youth's Battle, 116-19, 125, 137-38; Close Up Foundation, 26th Amendment, 4; Cretan, "Twenty-sixth Amendment," 575. For an account of the political calculations and maneuvering behind Mansfield, Kennedy, and Magnuson's actions, see John W. Finney, "How 18-Year-Olds Got the Vote," in The New York Times Guide for New Voters, ed. Harold Faber (New York, 1972), 76-83. 
cluding Iowa, initiated legal action soon after the Voting Rights Act passed to get the U.S. Supreme Court to settle questions about its constitutionality. At the end of December 1970 the Court, in a five-to-four decision, ruled that although Congress had the authority to lower the voting age to 18 in federal elections, it could not lower the voting age for state and local elections by means of statute. ${ }^{12}$ As a result, nearly all of the states faced the prospect of a complicated and expensive dual voting system to make sure that 18 - to 20 -year-olds did not vote for state and local candidates and referendums. ${ }^{13}$

Moving quickly to rectify the situation created by the Supreme Court, Congress proposed the Twenty-sixth Amendment in March 1971. The amendment read, "The right of citizens of the United States, who are eighteen years of age or older, to vote shall not be denied or abridged by the United States or any State on account of age." ${ }^{14}$ On April 1, 1971, Iowa became the eleventh state to ratify the amendment. ${ }^{15}$ Ratification was completed two months later. The Twenty-sixth Amendment officially became part of the U.S. Constitution on July 5, $1971 .{ }^{16}$ More than 11 million 18- to 20-year-olds now had the right to vote in federal, state, and local elections. ${ }^{17}$

12. Oregon v. Mitchell, 400 U.S. 112 (1970). See also Kyvig, Explicit and Authentic Acts, 366-67; Cultice, Youth's Battle, 170-74; Cretan, "Twenty-sixth Amendment," 575-76; Congressional Quarterly Service, Congress and the Nation: A Review of Government and Politics, vol. 3, 1969-1972 (Washington, DC, 1973), 1005; and New York Times, 12/22/1970, 1.

13. Alan P. Grimes, Democracy and the Amendments to the Constitution (Lexington, MA, 1978), 142-45; Keyssar, Right to Vote, 281; Cultice, Youth's Battle, 17781; New York Times, 12/22/1970, 1.

14. Cultice, Youth's Battle, 181-91; Congressional Quarterly Service, Congress and the Nation, 1005; Cretan, "Twenty-sixth Amendment," 576; John R. Vile, Encyclopedia of Constitutional Amendments, Proposed Amendments, and Amending Issues, 1789-1995 (Santa Barbara, CA, 1996), 325; U.S. Constitution, amend. 26, sec. 1.

15. The vote to ratify was 44-6 in the Iowa Senate and 94-6 in the Iowa House. Daily Iowan, 3/31/1971.

16. Kyvig, Explicit and Authentic Acts, 367-68; Cultice, Youth's Battle, 192-94, 196-97, 200-215; Close Up Foundation, 26th Amendment, 5-6; Congressional Quarterly Service, Congress and the Nation, 1005; Vile, Encyclopedia of Constitutional Amendments, 325; Cretan, "Twenty-sixth Amendment," 576; New York Times, 7/1/1971, 1; Washington Post, 7/6/1971, A1.

17. Of the 11 million 18- to 20-year olds, four million were college students, nine hundred thousand were in high school, 4.1 million were full-time workers, one 


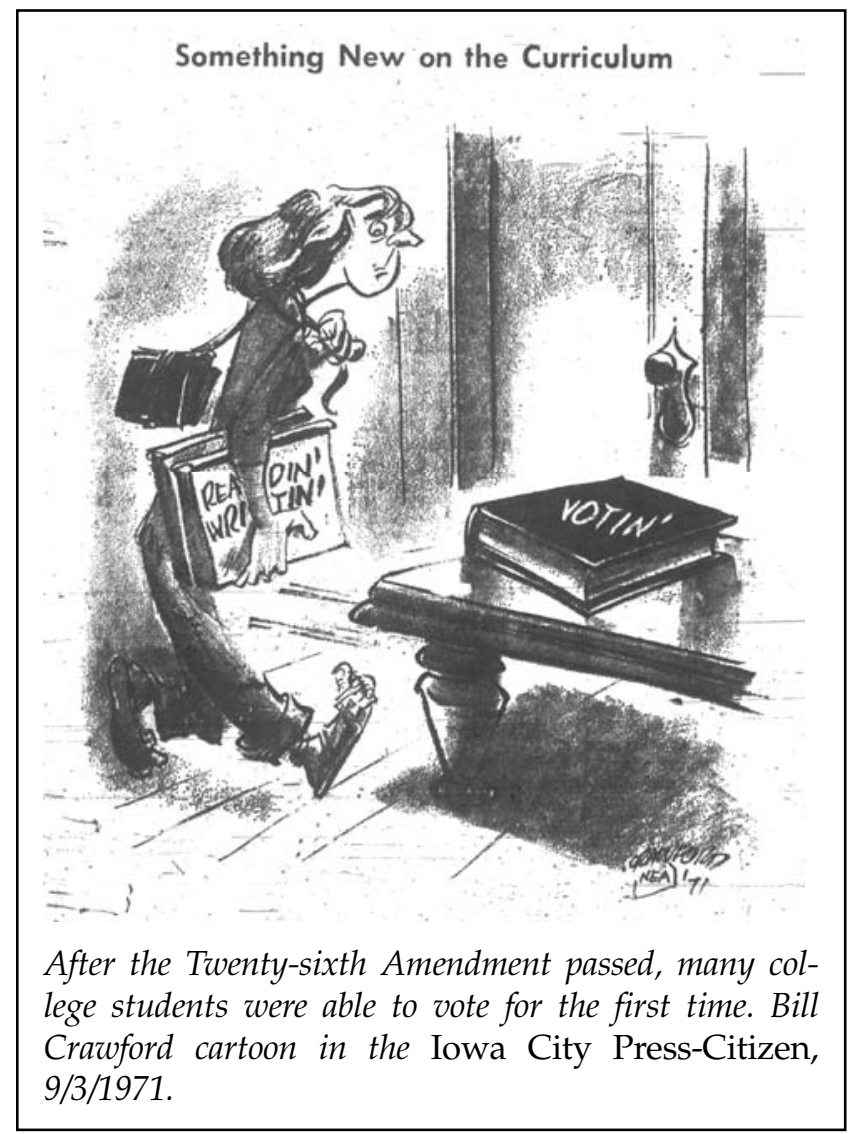

After passage of the Twenty-sixth Amendment, state and local officials had to decide whether to allow college students to register and vote in the community where they attended school. This was a controversial issue because student voters outnumbered permanent residents in some college towns. Incumbents worried that the youngsters would vote them out of office. Residents feared higher taxes if student voters passed expensive bond issues or elected free-spending city councils and school boards, and Republicans worried that Democratically inclined

million were homemakers, and eight hundred thousand were in the military. See U.S. Bureau of the Census, "Characteristics of New Voters," tables 1, 8, and 11, in Current Population Reports, Series P-20, No. 230 (Washington, DC, 1972). 
young people would end their party's political dominance in certain communities. $^{18}$

Iowa's Secretary of State Melvin Synhorst (R) met with local election officials on August 5, 1971, to discuss college town voting and other issues related to the 18-year-old vote. At the meeting, Iowa Attorney General Richard Turner (R) reiterated his October 1970 opinion that college students could vote in the towns where they attended school only if they were "born and raised there" or planned to reside there "for a substantial time" after graduation. ${ }^{19}$ Turner's opinion, which did not carry the force of law, was a more stringent standard than Iowa's "normal" residency requirement for voters. The normal residency rule required that the prospective voter be a resident (1) of the state for at least six months, (2) of the county for at least 60 days, and (3) of the precinct for at least ten days, all based on the date of the election, not the date of registration..$^{20}$ Election officials in Ames, Cedar Falls, and Iowa City decided to disregard Turner and apply the state's normal residency requirement when registering student voters. ${ }^{21}$

To encourage 18 - to 20 -year-olds to vote, a number of national organizations launched voter registration drives. The most active group in Iowa was Allard Lowenstein's Register for Peace. Lowenstein, a former New York congressman and newly elected national chairman of Americans for Democratic Action (ADA), had helped engineer the "Dump Johnson" movement in

18. "College-Town Worry: Will 18-to-21 Voters Take Over?" U.S. News and World Report, 9/6/1971, 38-41; "Youth Vote: Gown vs. Town," Newsweek, 8/30/1971, 27, 29; New York Times, 7/12/1971, 1. For a detailed account of the debate over college student voting, see Kenneth L. Eshleman, Where Should Students Vote?: The Courts, the States and Local Officials (Lanham, MD, 1989).

19. Des Moines Register, 8/6/1971; Ames Daily Tribune, 8/7/1971.

20. "What Iowa Law Says on Registration and Voting," in Register for Peace Agenda, August 28-29, 1971, Government of the Student Body (GSB) Papers, ISU Archives, ISU Library. Iowa law did not require voter registration in all cities and counties; only counties with a population of 50,000 or more and cities with a population of 10,000 or more needed a voter registration system.

21. Ames Daily Tribune, 8/11/1971; Des Moines Register, 8/7/1971, 8/11/1971. Other college towns were not as open to student voting in 1971 as Ames, Cedar Falls, and Iowa City were. For instances across the country where local election officials impeded the registration of student voters in college towns, see New York Times, 11/11/1971, 1 . 


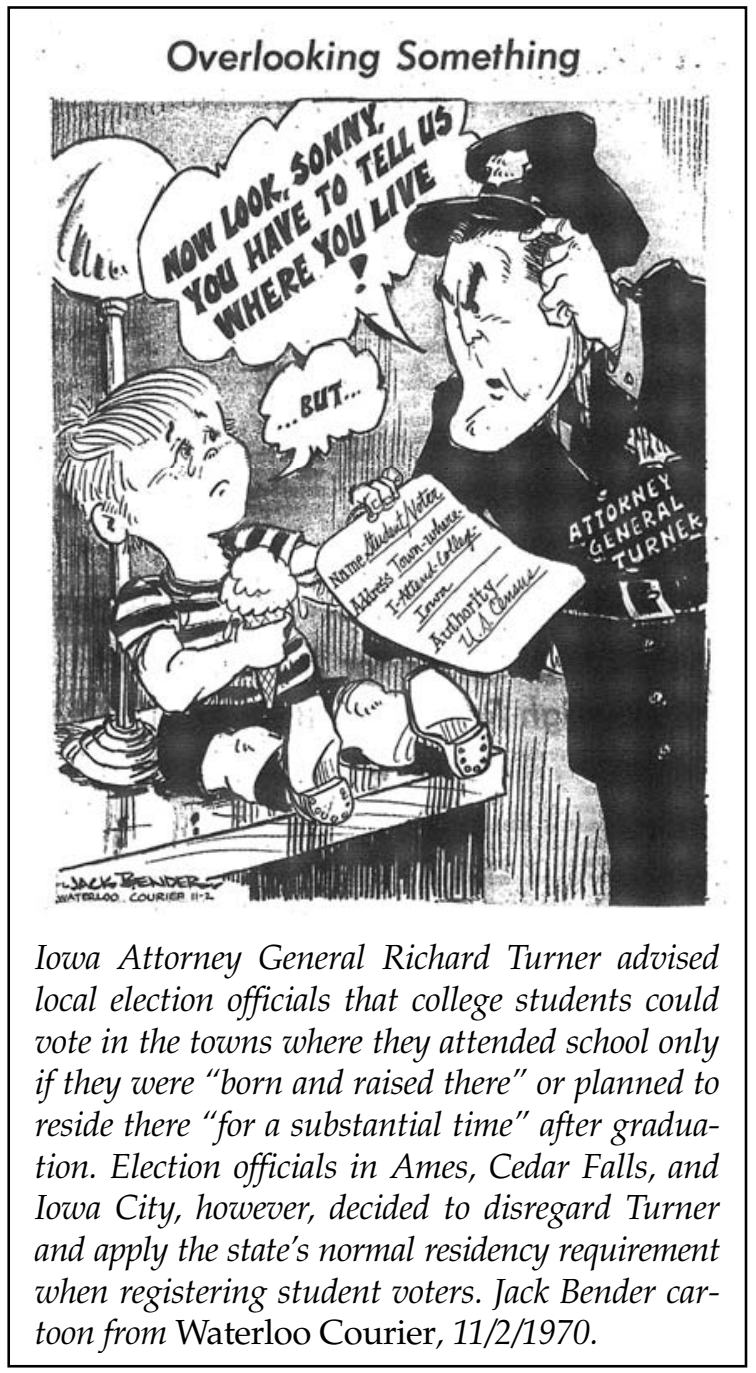

1968 that played a role in the McCarthy and Kennedy candidacies and President Lyndon Johnson's decision not to seek reelection. In 1971 Lowenstein was looking ahead to the 1972 presidential election. He hoped to build a "Dump Nixon" movement to oust then President Richard Nixon by marshalling the votes of newly enfranchised young people. ${ }^{22}$

22. Jonathan Cottin, "Democrats Actively Court Youth Vote; Republicans Shun Registration Campaign," National Journal, 9/18/1971, 1919; Richard Cummings, 
In late summer a representative from Lowenstein's group came to Ames to organize a statewide Register for Peace conference at ISU with help from local student activists. ${ }^{23}$ About 300 college and high school students from throughout Iowa attended the two-day conference at the end of August. It featured opening remarks by University of Iowa Writers' Workshop professor and author Vance Bourjaily, speeches by Iowa politicians, including Democratic gubernatorial candidate John Tapscott, Republican Lieutenant Governor Arthur Neu, and Democratic U.S. Congressman John Culver, a keynote address by Lowenstein titled "What the Youth Vote Means for the Nation," and entertainment by Peter Yarrow of the folk group Peter, Paul, and Mary. Conference participants also attended workshops on registering voters, the Iowa precinct caucus system, and running a political campaign. Local newspapers in Iowa City, Ames, and Cedar Falls and the Des Moines Register and the Tribune all ran stories about the conference, as did the student newspapers at UI, ISU, and UNI. ${ }^{24}$

VOTING is not, despite how one article from the 1970s put it, a "simple act." 25 The decisions of whether to participate in an election and for whom to cast one's ballot are well studied but complex phenomena. ${ }^{26}$ Both acts involve interplay between

The Pied Piper: Allard K. Lowenstein and the Liberal Dream (New York, 1985), 33643, 347-54, 428-35; William H. Chafe, Never Stop Running: Allard Lowenstein and the Struggle to Save American Liberalism (New York, 1993), 262-90, 360-63; "Man to Watch," Newsweek, 8/23/1971, 21; Washington Post, 3/25/1971, A20.

23. Des Moines Register, 8/9/1971; Ames Daily Tribune, 8/11/1971.

24. Register for Peace Agenda, GSB Papers; Des Moines Register, 8/30/1971; Des Moines Tribune, 8/30/1971; Ames Daily Tribune, 8/30/1971; Iowa State Daily, 9/7/1971; Iowa City Press-Citizen, 8/27/1971, 8/30/1971; Daily Iowan, 9/2/1971; Cedar Falls Record, 8/19/1971, 8/31/1971; Northern Iowan, 10/5/1971; Waterloo Daily Courier, 8/19/1971; Waterloo Sunday Courier, 8/29/1971.

25. Stanley Kelley Jr. and Thad W. Mirer, "The Simple Act of Voting," American Political Science Review 68 (1974), 572-91.

26. The research on who votes is voluminous. For a touchstone on this topic, see Raymond E. Wolfinger and Steven J. Rosenstone, Who Votes? (New Haven, CT, 1980). See also Richard G. Niemi and Herbert F. Weisburg, Controversies in Voting Behavior (Washington, DC, 2001), 22-38; and Nelson W. Polsby and Aaron Wildavksy with David A. Hopkins, Presidential Elections: Strategies and Structures of American Politics (Lanham, MD, 2008), 5-26. 
electoral rules, the individual voter, the candidates, and other political actors.

Election rules have consequences. ${ }^{27}$ Local elections can be partisan affairs with candidates running on party labels, or they can be nonpartisan. The second option grew out of the Progressive movement at the turn of the twentieth century and has the consequence of reducing the influence of political parties and political machines. ${ }^{28}$ Local officials can be elected at large or they can be elected on the basis of subjurisdictions, such as a ward system. Election rules also state whether the winning candidate in an election needs a majority of votes cast or only a plurality. Determining who wins often involves a primary election. The most common form of primary winnows the field of candidates down to ensure a majority winner for each office in the general election. Another form of primary, the runoff primary, creates a subsequent contest between the top two plurality vote getters. At-large elections, the majority winner standard, and primary elections are designed to strengthen the power of broader, politically active constituencies in the community at the expense of numerically smaller, more geographically concentrated populations.

Another election rule of special importance for the elections described in this article is the requirement that citizens have to register before they can vote in an election. In the United States, unlike most other western-style democracies, the onus is on the individual to take the bureaucratic step to become registered. The argument in favor of registering voters is that it prevents voter fraud. It does accomplish that purpose, but it also reduces voter participation by creating a prerequisite for voting. In 1971, long before postcard and e-mail voter registration, and before the Motor Voter Act of 1993, voter registration requirements were a significant barrier to voter participation. ${ }^{29}$

27. On the general point that election rules and voting systems are not neutral, see Douglas W. Rae, The Political Consequences of Electoral Law (New Haven, CT, 1971); and Douglas J. Amy, Behind the Ballot Box (Westport, CT, 2000), esp. chaps. 1 and 6.

28. John Whiteclay Chambers II, The Tyranny of Change: America in the Progressive Era, 1900-1917 (New York, 1980), 105-39.

29. See Steven J. Rosenstone and Raymond E. Wolfinger, "The Effects of Registration Laws on Voter Turnout," American Political Science Review 72 (1978), 2245; G. Bingham Powell, "American Voter Turnout in Comparative Perspective," 


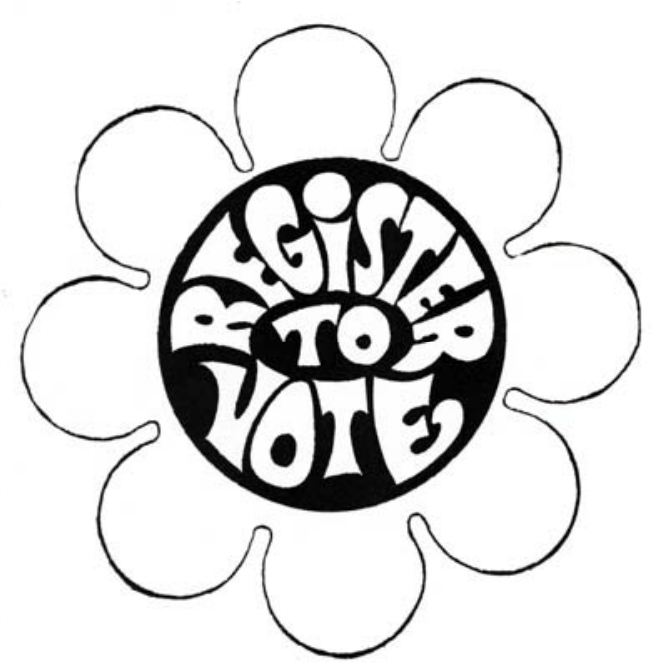

The University of Iowa student newspaper used the "flower power" symbol popular in the late 1960 s and 1970s to encourage students to register to vote. The Daily Iowan, 9/3/1971.

Some individuals are sufficiently self-motivated to register and vote; others are not. High socioeconomic status (SES) individuals are more likely to register than low SES individuals. One component of SES is an individual's level of education, a characteristic that college students rate high on in comparison to others in society. But college students are younger than other voters and usually have fewer ties to the community where they are residing, both factors that make it less likely that an individual will participate in local elections. Also, by definition, 18- to 20-year-olds have not developed the "habit" of voting, which recent studies of American elections have shown to be important. Furthermore, voter registration deadlines several

American Political Science Review 80 (1987), 17-43; Robert W. Jackman, "Political Institutions and Voter Turnout in Industrial Democracies," American Political Science Review 81 (1986), 405-23; and Mark J. Fenster, "The Impact of Allowing Day of Registration Voting on Turnout in U.S. Elections from 1960 to 1992: A Research Note," American Politics Quarterly 22 (1994), 74-87. 
weeks before Election Day make it likely that many citizens will not be foresighted enough to register on time. ${ }^{30}$

Because of these impediments to registering and voting, election organizations and activists, if they have the capacity, engage in mobilization efforts to encourage and facilitate the participation of voters who would not participate on their own. ${ }^{31}$ Political mobilization takes many forms - registering citizens to vote, providing voters with information, and contacting voters by various means to encourage voting - but such efforts do not automatically increase political participation. Rather, recent research suggests the importance of social influences, such as social networks and peer pressure, preexisting motivation, feelings of obligation and solidarity, and the absence of anonymity, for facilitating increased participation. ${ }^{32}$

Political mobilization can sometimes influence how a voter votes. It is not the only consideration, but it can be a very important one under certain conditions. Other factors can also be important, such as an individual's political party affiliation if it is a partisan election, candidate characteristics (photogenic or not, likeability factor, celebrity status, gender, ethnicity, etc.), and salient issues (war and peace, the economy, crime, etc.). ${ }^{33}$

30. Sidney Verba and Norman H. Nie, Participation in America: Political Democracy and Social Equality (New York, 1972); Wolfinger and Rosenstone, Who Votes?, 46-60; Michael M. Gant and Norman R Luttbeg, American Electoral Behavior (Itasca, IL, 1991), 103-4; Alan S. Gerber, Donald P. Green, and Ron Shachar, "Voting May Be Habit-forming: Evidence from a Randomized Field Experiment," American Journal of Political Science 47 (2003), 540-50; Donald P. Green and Ron Shachar, "Habit Formation and Political Behavior: Evidence of Consuetude in Voter Turnout," British Journal of Political Science 30 (2000), 561-73.

31. The classic work on this topic is Steven J. Rosenstone and John Mark Hansen, Mobilization, Participation, and Democracy in America (New York, 1993), esp. chaps. 2 and 6.

32. Researchers at Yale University's Institute of Social and Policy Studies and others have conducted a series of large-scale, real world experiments on various get-out-the-vote (GOTV) techniques over the past two decades that have been published in a large number of journal articles and summarized in Alan S. Gerber and Donald P. Green, Get Out the Vote: How to Increase Voter Turnout (Washington, DC, 2008). See also Green and Gerber's edited volume The Science of Voter Mobilization (Thousand Oaks, CA, 2005). For a sense of how GOTV was done in the less technologically sophisticated 1970s, see Dick Simpson, Winning Elections: A Handbook in Participatory Politics (Chicago, 1972).

33. For textbook treatments of the topic of vote choice, see Kenneth Janda, Jeffrey M. Berry, and Jerry Goldman, The Challenge of Democracy, 9th ed. (Boston, 
Nonpartisan elections lack the voting cue - party label - that political scientists have identified as being the most important vote determinant and, as a consequence, increase the possibility that other "cues" will become important. Candidates and issues are short-term factors that vary by election and office. Political mobilization is not a purely mechanical task; all political mobilization is not equal. To be effective, political activists must have credibility in the eyes of those they hope to influence, and research has shown that messages from political elites to voters for support will be more effective if they do not have to compete with conflicting messages from other elites. ${ }^{34}$

Political mobilization does not occur out of the goodness of anyone's heart; rather, it takes place to achieve political advantage. Activists make the effort because they believe it will gain them votes on Election Day. It is relatively rare to blindly mobilize demographic groups of people because individuals in a complex society such as the United States usually do not vote in lock-step fashion; voters are not as uniform in their interests and experiences as a first glance often makes it appear. Block voting by sociodemographic groups, referred to as reference group effects, is not usually much of a factor in American elections. Yet that is what Allard Lowenstein and other activists were trying to do; they hoped to get out the "student vote" in the expectation that students would vote en masse for an antiwar candidate and defeat President Nixon.

In 1971 university students were an ideal cohort for political mobilization. They were relatively homogenous in their sociodemographic characteristics; they shared a similar youth culture and common life experiences; many of them felt threatened by and therefore opposed the Vietnam War; they favored the environmental and women's movements developing at the time; they lived in close geographical proximity to each other; some, especially antiwar leaders, had had unsatisfactory experiences

2008), 287-91; Abramson, Aldrich, and Rohde, Change and Continuity, 134-206; and Niemi and Weisberg, Controversies in Voting Behavior, 180-99.

34. John Zaller, The Nature and Origins of Mass Opinion (New York, 1992), 8-9; David M. Paul and Clyde Brown, "Testing the Limits of Elite Influence on Public Opinion: An Examination of Sports Facility Referendums," Political Research Quarterly 54 (2001), 871-88. 
with local law enforcement officials; and they had established channels of communication within their student communities. ${ }^{35}$ The student activists involved in the elections in Ames, Cedar Falls, and Iowa City sought to involve their fellow students across the board in winning local political power to further their interests.

IOWA STATE UNIVERSITY was established in the 1860s as a college of "agriculture and mechanic arts" under the terms of the federal Morrill Land Grant Act. ${ }^{36}$ It is located in Ames, a city in central Iowa about 30 miles north of Des Moines. According to the U.S. census, Ames's population approached 40,000 in 1970 (see table 1). Ames residents were overwhelmingly white and were better educated and wealthier than the state as a whole. Minorities, including African Americans, numbered about 1,000. Almost 90 percent of Ames adults had finished high school and 45 percent had a college degree. Median family income was 10 percent higher than the rest of Iowa. Almost half of Ames's workers were employed in public sector jobs. ${ }^{37}$

35. For a theory of protest behavior that explicitly incorporates many of these points and is easily adaptable to the situation of university students during the Vietnam War era, see Neil J. Smelzer, Theory of Collective Behavior (New York, 1963); and Jerry M. Lewis, "A Study of the Kent State Incident Using Smelser's Theory of Collective Behavior," Sociological Inquiry 42 (1972), 87-96.

36. National Association of State Universities and Land-Grant Colleges, The Land-Grant Tradition (Washington, DC, 1995), 3-4, 10, 12-13; Coy F. Cross II, Justin Smith Morrill: Father of the Land-Grant Colleges (East Lansing, MI, 1999), 84-85; Dorothy Schwieder and Gretchen Van Houten, eds., A Sesquicentennial History of Iowa State University: Tradition and Transformation (Ames, 2007), 11-12; Earle Ross, A History of Iowa State College of Agriculture and Mechanic Arts (Ames, 1942), 35-44.

37. U.S. Bureau of the Census, County and City Data Book, 1972: A Statistical Abstract Supplement (Washington, DC, 1973), 690-701. According to the rules of residence in effect for the 1970 U.S. census, college students living away from home were to be counted as living in their college towns. However, the census undoubtedly undercounted university students in Ames, Cedar Falls, and Iowa City. In 1973 the Census Bureau conceded that it had undercounted the 1970 U.S. population by 5.3 million persons, but little can be said definitively about the degree of undercount in specific locations, including the three cities that are the focus of this article. Almost 2,000 official undercount complaints, including some from university cities, were filed against the 1970 census. States and communities often dispute their census figures because the stakes are high in terms of congressional representation and the allocation of federal 
TABLE 1

SELECTED 1970 DEMOGRAPHIC CHARACTERISTICS OF AMES, CEDAR FALls, IOWA CITY, AND THE STATE OF IOWA

\begin{tabular}{lcccc}
\hline & Ames & $\begin{array}{c}\text { Cedar } \\
\text { Falls }\end{array}$ & Iowa City & Iowa \\
\hline $\begin{array}{l}\text { Population } \\
\text { White }\end{array}$ & 39,699 & 29,504 & 48,850 & $2,824,376$ \\
$\begin{array}{l}\text { Population } \\
\text { Growth, 1960- }\end{array}$ & $46.6 \%$ & $98.9 \%$ & $98.0 \%$ & $98.6 \%$ \\
$\begin{array}{l}\text { 1970 } \\
\text { High School }\end{array}$ & $87.1 \%$ & $78.2 \%$ & $82.1 \%$ & $59.0 \%$ \\
$\begin{array}{l}\text { Graduates } \\
\text { College }\end{array}$ & $44.4 \%$ & $22.0 \%$ & $39.4 \%$ & $9.1 \%$ \\
$\begin{array}{l}\text { Graduates } \\
\text { College }\end{array}$ & 14,966 & 6,390 & 14,232 & 97,219 \\
$\begin{array}{l}\text { Enrollment } \\
\text { Median Family }\end{array}$ & $\$ 10,126$ & $\$ 10,913$ & $\$ 9,942$ & $\$ 9,016$ \\
$\begin{array}{l}\text { Income } \\
\text { Low Income }\end{array}$ & $7.1 \%$ & $6.4 \%$ & $7.2 \%$ & $8.9 \%$ \\
$\begin{array}{l}\text { Government } \\
\text { Sector } \\
\text { Employment }\end{array}$ & $46.3 \%$ & $22.0 \%$ & $39.4 \%$ & $14.5 \%$ \\
\hline
\end{tabular}

SOURCE: U.S. Bureau of the Census, County and City Data Book, 1972: A Statistical Abstract Supplement (Washington, DC, 1973), 690-701.

*For fall 1971, ISU enrolled 21,261 students; UNI, 9,605; and UI, 20,387. All of these numbers are considerably higher than those reported in the census data. For a variety of reasons, the two sets of numbers are not strictly comparable. See Iowa State University General Catalog, 1973-1975, 303; Cedar Falls Record, 10/7/1971; and Iowa City Press-Citizen, 10/1/1971.

ISU enrolled slightly more than 21,000 students in 1971. Nearly 11,000 students were enrolled in ISU's professional schools - the colleges of agriculture, education, engineering, home economics, and veterinary medicine - during the 197172 academic year. About 6,700 students were in the College of Science and Humanities and 3,300 in the Graduate College. The student body was two-thirds male and 97 percent white. Four-

funds. See New York Times, 4/26/1973, 1; Robert B. Hill, "Estimating the 1970 Census Undercount in States and Local Areas," Urban League Review 1-2 (1975), 36-45; Harvey M. Choldin, Looking for the Last Percent: The Controversy over Census Undercounts (New Brunswick, NJ, 1994), 30-33; and Margo J. Anderson and Stephen E. Fienberg, Who Counts? The Politics of Census-Taking in Contemporary America (New York, 1999), 41-48. 
fifths of the students came from Iowa, mostly from small towns and rural areas. ${ }^{38}$

Several factors came together in 1971 to allow ISU students to have a decisive impact on the November election. First, a small group of antiwar activists, nursing a grievance against the city attorney for his treatment of demonstrators in May 1970, were ready to work to elect members of city council pledged to remove him from office. Second, a larger group of activists, energized by Lowenstein's Register for Peace Conference, were motivated to add their fellow students to the voter rolls to increase student voting power in the fall election. Finally, older activists were on hand to give the students advice on choosing viable candidates and running a labor-intensive door-to-door local election campaign. ${ }^{39}$

In Ames, student mobile registrars were used extensively to register students to vote. Iowa election law allowed voters to be registered by mobile registrars appointed by the Democratic and Republican county parties and deputized by the city clerk or county auditor. Initially, just two ISU students, Clyde Brown and Kevin Kirlin, worked on the registration drive, but eventually at least 20 students, most prominently graduate student John W. Hugg, were involved in the effort. ${ }^{40}$ Brown and Kirlin, both of whom were active in the antiwar movement and in local Democratic Party politics and had helped organize the Register for Peace conference, initially worked without the sanction or sponsorship of any university organization. In mid-September,

38. Iowa State University General Catalog, 1971-1973, 91-92; Iowa State University General Catalog, 1973-1975, 303; Leigh Elsberry, Office of Institutional Research, ISU, e-mails to Clyde Brown, 6/11/2003 and 6/16/2003. In fall 1971 there were 681 minority students at Iowa State, 392 of whom were foreign students. Elsberry, e-mail, 6/11/2003. For more on ISU during this time period, see Robert Underhill, Alone among Friends: A Biography of W. Robert Parks (Ames, 1999), 117-72 (Parks was ISU president, 1965-1986); and Schweider and Van Houten, eds., Sesquicentennial History of ISU, 77-102, 163-65, 226-29.

39. For a more detailed account of the November 1971 Ames municipal election, see Clyde Brown and Gayle K. Pluta Brown, "'Moo U' and the 26th Amendment: Registering for Peace and Voting for Responsive City Government," Peace and Change 29 (2004), 48-80.

40. Iowa State Daily, 9/16/1971. Individuals could also register at the Ames city hall or the courthouse in Nevada, county seat of Story County, ten miles east of Ames. 


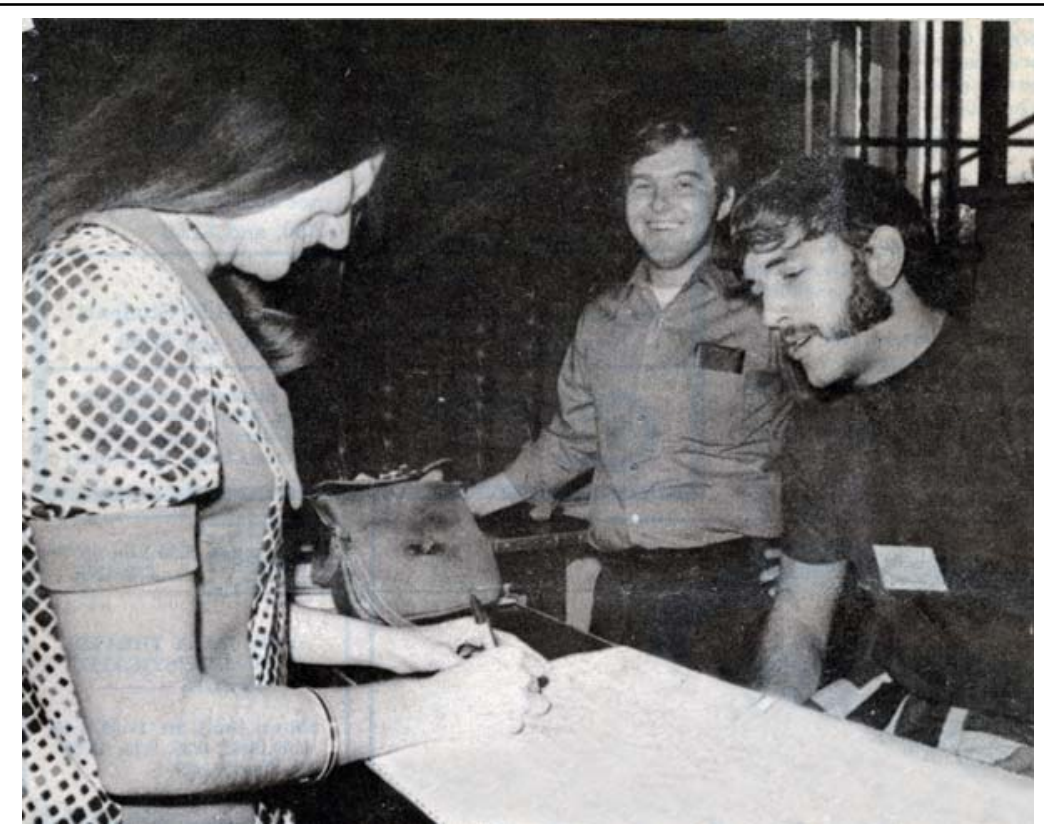

Clyde Brown (left) and Steve Waugh register students at the Memorial Union on the ISU campus. From Iowa State Daily, 9/29/1971.

however, the ISU Government of the Student Body (GSB) launched a voter registration drive that effectively incorporated the efforts of the two. ${ }^{41}$ Besides staffing a voter registration booth in the Memorial Union on campus, the student mobile registrars went door-to-door in dormitories, fraternities, sororities, and married student housing. They were on hand to register students at rallies and dances on campus and went so far as to set up registration tables outside the state liquor store and campus town bars on weekends. ${ }^{42}$ The registration drive resulted in at least 3,125 new voters, a figure that fell short of the

41. "Senate Bill \#40: Establishment of a Director of Voter Registration, September 7, 1971," GSB Papers; Iowa State Daily, 9/14/1971, 9/16/1971.

42. John W. Hugg, conversation with Clyde Brown, 12/19/2001; Steve Zumbach, Don Nickerson, Shellie Sinks, and Mack Teachout, letter to Mobil Registers [sic], 9/20/1971, GSB Papers; "Voter Registration Drive Falls Short of Goal," Bomb: Yearbook of Iowa State 79 (1972), 94-95; Iowa State Daily, 9/17/1971, 9/29/1971, 10/15/1971, 10/20/1971; author Clyde Brown's recollection. 
GSB goal of 5,000 but satisfied activists who wanted students to have an impact on the November election. ${ }^{43}$

Student activists had assistance from the staff of the AmesISU Young Men's Christian Association (YMCA) as they contemplated candidates in the upcoming election. James Rhoads, executive director of the YMCA, and Don Christensen, the Y's student program coordinator, were part of a small group that had been talking informally for some time about getting "strong, independent, progressive candidates" to run for the Ames City Council. They were motivated by a general concern about the direction of the current city administration as well as the more specific concern that "the power of law enforcement was being used inappropriately." ${ }^{44}$ In 1971 the Y leadership wanted to help youth runaways and drug users who were being arrested by Ames police. The YMCA opened a drop-in center to give troubled young people, especially those of high school age and younger, a safe place to gather where they could socialize and receive counseling without risking arrest. ${ }^{45}$ The Y's leadership felt that the attitude of local law enforcement officials - police, prosecutors, and judges - made it difficult to carry out its missions to young people on and off campus.

The YMCA leadership also worried about the influence City Attorney James Bishop exerted in the current administration. ${ }^{46}$ Student antiwar activists shared this concern. Bishop had angered antiwar protesters by what they considered his aggressive handling of the May 1970 sit-in at the Story County draft board and subsequent events. Rather than negotiate with protesters, Bishop had ordered their immediate arrest. Police then used tear gas to clear the stairway leading to the draft board office and

43. The Ames city clerk reported 3,957 new voter registrations since the September 13, 1971, school board election, with student mobile registrars signing up 3,125 people. Ames Daily Tribune, 11/1/1971; Iowa State Daily, 10/30/1971; "Voter Registration Drive Falls Short," 94.

44. Dennis Kelso, telephone conversation with Clyde Brown, 3/8/2002. Kelso, an Ames native, worked for the YMCA in the fall of 1971 and had previously been a program adviser for the ISU Dean of Students Office.

45. Youth and Shelter Services, Inc.: A History of the Early Years (Ames, 2001), 6-7.

46. Don Christensen, e-mail to Clyde Brown, 12/28/2001; Dennis Kelso, telephone conversation with Clyde Brown, 3/1/2002; Kelso, telephone conversation, 3/8/2002. 
took 23 students to jail. Many believed that Bishop displayed a disregard for student rights. He was quoted as telling a female student, "You don't need to know anymore about your rights than a hog does Sunday." ${ }^{47}$ Bishop's retention as city attorney would become an important issue in the election campaign.

This informal group of YMCA staff members and antiwar activists soon joined with past and present GSB officers and representatives from the Young Women's Christian Association (YWCA) and the ISU Dean of Students Office to meet with announced and potential candidates. Eventually the group formed a more permanent organization that they called the Coalition for Responsive City Government (CRCG) to coordinate election activities. In planning the election campaign, the CRCG had the assistance of individuals who had worked in Chicago to elect Democratic city council candidates opposed to the political machine of then Mayor Richard M. Daley and had been trained by renowned radical community organizer Saul Alinsky. ${ }^{48}$

At stake in the nonpartisan general election were the mayor's office, two at-large city council seats, the Second and Fourth Ward council seats, and the park commissioner's post. Rather than run a slate of student candidates, the CRCG, on the advice of its YMCA mentors, looked for candidates who not only shared their positions on issues but could also appeal to a broad range of voters and serve on council effectively.

Using those criteria, the CRCG endorsed Barbara Koerber for one at-large seat, Charles Calhoun for the other at-large post, Russell Pounds for the Fourth Ward position, and Kenneth Lane

47. Brown and Brown, "Moo U and the Cambodian Invasion," 128-29; Jerry Parkin, "An Open Letter to Scott County," 5/14/1970, GSB Papers. Parkin, then vice-president of the ISU GSB, reassured residents of Scott County in eastern Iowa that antiwar protests at ISU in May 1970 had been peaceful; he presented student demonstrators in a positive light, in part by contrasting them to Bishop.

48. Iowa State Daily, 10/20/1971, 10/26/1971, 10/29/1971; Ames Daily Tribune, 10/25/1971; Christensen, e-mail, 12/28/2001. Saul Alinsky, author of Reveille for Radicals (1946) and Rules for Radicals (1971), spent more than 40 years working to organize residents of poor and working-class neighborhoods. His methods continue to be used by community organizers throughout the United States. For more on Alinsky, see Stanford D. Horwitt, Let Them Call Me Rebel: Saul Alinsky - His Life and Legacy (New York, 1989).

49. Kelso, telephone conversations, 3/1/2002,3/8/2002. 
for park commissioner. Koerber, active in the League of Women Voters, had run unsuccessfully as a Democrat for the state senate the previous year. She was unopposed in the city council race, but the CRCG hoped a strong showing by Koerber would give her greater influence on the new city council. Pounds, an ISU extension economist, had served as director of the Des Moines Model Cities program. When elected, he became the first African American to serve on the Ames City Council. Calhoun, a small business owner, had impressed CRCG members in the candidate interviews. Lane was an assistant professor of landscape architecture at ISU. The group did not endorse a candidate for mayor because it did not have a preference for either of the two candidates and did not endorse a candidate in the Second Ward because few students lived there..$^{50}$

Most students resided in the Third Ward on Ames's south side and the Fourth Ward on the west side. The CRCG concentrated on three precincts in the Third and Fourth Wards. Precinct 4-1 (Fourth Ward, Precinct 1) was located west of campus and comprised high-density rental housing; precinct 4-3, encompassing the ISU campus, included four major dormitory complexes and university housing for married students; and precinct 3-2, south of campus, contained student apartments, 14 sororities, 36 fraternities, and another dormitory complex.

The CRCG embarked on a classic voter education, voter identification, and get-out-the-vote (GOTV) campaign. ${ }^{51}$ It produced literature that prominently displayed its candidate endorsements. Members of the coalition went door-to-door to encourage students to vote for the endorsed slate of candidates. CRCG representatives attended the eight candidate forums held in the weeks leading up to the election. Among the issues discussed were the need for low-income housing in the city, enforcing the housing code's health and safety standards, providing special pathways for bicycles, continuing taxpayer support for the bus system, and including ISU students on city committees.

50. Iowa State Daily, 9/28/1971, 10/1/1971, 10/6/1971, 10/21/1971, 10/22/ 1971, 10/29/1971; Ames Daily Tribune, 9/27/1971, 10/1/1971, 10/5/1971, 10/25/1971, 10/26/1971; Des Moines Register, 10/31/1971, 11/3/1971; Kelso, telephone conversation, $3 / 1 / 2002$.

51. Iowa State Daily, 10/29/1971. 
The future of City Attorney Bishop also was discussed. Koerber and Pounds pledged not to rehire Bishop. Calhoun did not commit himself to Bishop's removal, but remarked, "I think we could do better." ${ }^{\prime 2}$

On the night before the election, CRCG members distributed slate cards in dormitories, fraternities, and sororities and placed doorknob hangers listing the endorsed candidates on off-campus homes and apartments. ${ }^{53}$ The next day coalition poll watchers in the targeted precincts kept track of which newly registered students had voted. During the day CRCG volunteers telephoned students who had not yet voted and urged them to get to the polls, sometimes contacting the same person more than once.

The CRCG's work paid off, as its entire endorsed slate swept into office. ${ }^{54}$ A record 7,506 votes were cast citywide. In two instances, the student vote provided the margin of victory (see table 2). Pounds won a three-person race with 59 percent of the vote. He needed a majority of all votes cast to avoid a runoff election. A remarkable 75 percent of the vote in precinct 4-3 clinched the race for him. Student voting power was most evident in the at-large race that Calhoun won by 267 votes. Calhoun lost in the First and Second Wards where few students lived, but he carried the Third and Fourth Wards by 1,020 votes, with 878 of that margin coming from the three targeted student precincts. Kenneth Lane easily won the park commissioner race with 62 percent; in the student GOTV precincts he racked up 78 percent of the vote.

The impact of the student vote was not lost on the winners. Calhoun said, "I couldn't have done it without the student help. It's awfully tough to beat an incumbent. But the student group got the votes for me. I wouldn't have gotten them otherwise." Likewise, Pounds felt that "students had a significant effect on my election. The endorsement helped, they got out the vote." In

52. Ames Daily Tribune, 10/18/1971.

53. Kevin M. Kirlin, conversation with Clyde Brown, 12/19/2001.

54. In other college towns in Iowa and across the United States, the student vote met with varying degrees of success in the November 1971 election. See Des Moines Register, 11/3/1971; and New York Times, 11/4/1971, 35. 


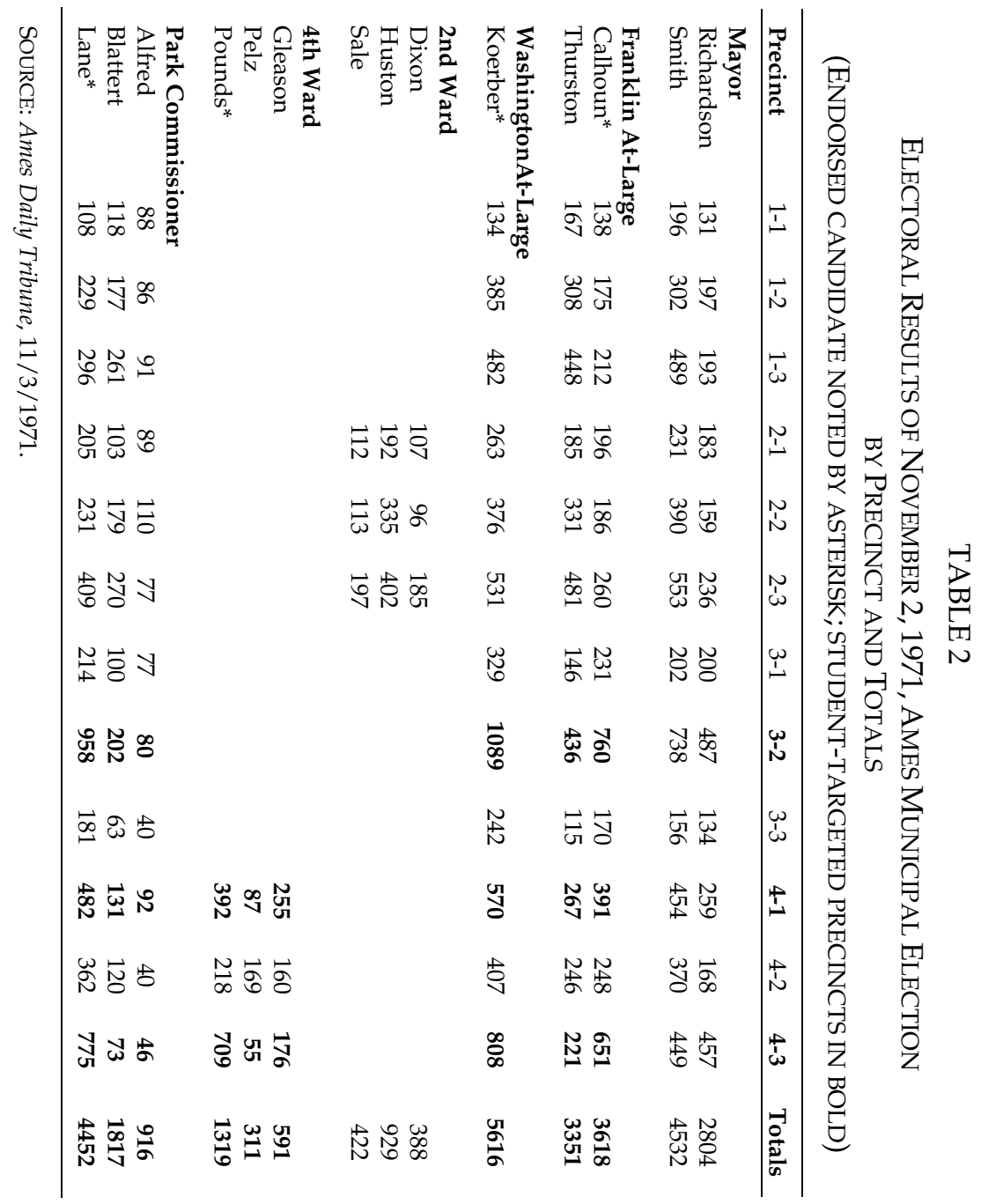


an editorial, the Ames Daily Tribune acknowledged "the concerted effort on the part of some young people to get their colleagues out to vote. . . . [The CRCG] know[s] how the system works and used that knowledge to bring about the election of the candidates they selected."

Soon after the newly elected candidates took office, the city council reappointed various city administrators, including City Attorney Bishop. All but Bishop received reappointment to the usual one-year term. The city attorney's reappointment was for nine months, a clear signal that he did not have the confidence of the new city council. In June, Bishop announced that he had accepted the position of city attorney in Kalamazoo, Michigan. ${ }^{56}$ The CRCG had achieved one of its main objectives.

THE UNIVERSITY OF NORTHERN IOWA is the youngest and smallest of Iowa's three public universities. Established in 1876 as a normal school for educating teachers, UNI achieved university status and took its current name in 1967. It is located in Cedar Falls, a community in northeast Iowa whose population numbered 30,000 in 1970 and is adjacent to the larger, industrial city of Waterloo. Compared to Ames and Iowa City, Cedar Falls at the time had a much smaller public sector and its citizens had less formal education, but, interestingly, the median family income was higher in Cedar Falls and the city had fewer low-income residents (see table 1). Like Iowa's other public universities, and, indeed, like colleges and universities throughout the United States, UNI experienced a significant increase in enrollment during the 1960s from 3,616 in 1960 to 9,723 in 1970. ${ }^{57}$ Of the three state universities, only at UNI did female students outnumber the men, a reflection of its longstanding mission to prepare young people for teaching careers in primary and secondary schools, a profession where women predominated.

55. Des Moines Tribune, 11/3/1971; Ames Daily Tribune, 11/3/1971.

56. Ames Daily Tribune, 6/7/1972; Kalamazoo Gazette, 6/6/1972. Bishop served as Kalamazoo's city attorney until 1977. Kalamazoo Gazette, 6/21/1977.

57. U.S. Bureau of the Census, County and City Data Book, 1972, 690-701; Rod Library, University of Northern Iowa, "UNI Fact Sheet," www.library.uni.edu/ collections/special-collections/uni-fact-sheet. 
Registering students to vote proved more controversial at UNI than the election itself. After some initial foot dragging, City Clerk Kenneth TeWalt established a branch voter registration office on campus for three days in mid-October 1971, but he turned down a request from the UNI Student Association (UNISA) to keep the campus location open additional days. Student leaders claimed that long lines had deterred many students from registering. In addition, on at least one occasion registrars ran out of forms and had to turn students away until they were resupplied. As it was, almost 700 individuals, most of them students, registered during the three-day event. ${ }^{58} \mathrm{~A}$ local Register for Peace Conference organized by UNI Young Democrats Vice-President Russ Bell coincided with the last day of the city clerk's campus voter registration operation. At Lowenstein's statewide meeting at ISU in August, Bell had been named chair of the Register for Peace district that included Cedar Falls. ${ }^{59}$

After TeWalt refused to keep the campus voter registration office open beyond October 16, UNISA President Keith Stamp published a letter to the editor in the Cedar Falls Record complaining about TeWalt's seeming lack of enthusiasm for registering student voters. Stamp recounted how UNISA's initial request for a campus voter registration site was bounced from the city clerk to the city attorney to the state attorney general's office before TeWalt gave his approval. "The rhetoric 'that we want to encourage all to vote' is unacceptable unless you follow through with the appropriate actions," Stamp wrote. When TeWalt refused to budge, the Student Association arranged car rides to city hall the two days before the October 23 voter registration deadline to give more students the opportunity to register. ${ }^{60}$

This was not the first time an effort to provide a place on campus for UNI students to register to vote met with less than enthusiastic support from local officials. In fall 1970 student

58. Minutes, Student Senate Meetings, 9/14/1971, 10/12/1971, 10/19/1971, UNI Student Association Papers, UNI Archives, Rod Library, UNI; Cedar Falls Record, 9/30/1971, 10/2/1971, 10/9/1971, 10/19/1971, 10/20/1971; Northern Iowan, 10/8/1971, 10/12/1971.

59. Minutes, Student Senate Meeting, 9/28/1971, UNI Student Association Papers; Northern Iowan, 10/5/1971, 10/12/1971.

60. Cedar Falls Record, 10/28/1971, 10/21/1971. 
mobile registrars, in an operation similar to the one that proved so successful on the ISU campus in 1971, had staffed a registration booth in the student union and managed to register 400 students. The booth was open for two hours each afternoon for several weeks before TeWalt asked that it be shut down on the grounds that the mobile registrars, who were not employees of the city or county, had in essence set up a branch registration office by operating from a single advertised location. Mobile registrars Phil Friedman and Jon Crews (the latter would run for mayor in 1971) ignored the request until ordered to close by Iowa Attorney General Richard Turner on October 21. ${ }^{61}$

UNI students who wanted to register to vote faced another problem - one that confronted UI students as well. Fall classes at UNI and UI started in mid-September, so it was usually not possible for first-year or transfer students who wanted to vote in the November 2,1971, election to meet the county residency requirement of 60 days. TeWalt was willing to let students who had been at UNI in spring 1971 register even if they had not spent the summer in Black Hawk County or Cedar Falls. ${ }^{62}$

In the November 2, 1971, election in Cedar Falls, the mayor's office, one at-large council seat, and the Second, Fourth, and Fifth Ward council seats were up for election. The incumbents in all those positions faced challengers. In addition, there were races for city treasurer, park commissioner, municipal court judge, municipal court clerk, hospital trustee, and riverfront commissioner. The candidates for all those positions were incumbents, except for two newcomers who were seeking the hospital trustee and riverfront commissioner positions. Of the second group, only the park commissioner faced a contested race.

Frank Williams, the incumbent mayor, had been in office only since April, when Mayor William McKinley had resigned

61. Minutes, Student Senate Meetings, 9/29/1970, 10/27/1970, UNI Student Association Papers; G. Michael Conlee to Richard C. Turner, in Minutes, Student Senate Meeting, 10/27/1970, UNI Student Association Papers; Northern Iowan, 2/9/1971. The UNI student newspaper and the Cedar Falls and Waterloo newspapers all gave extensive, often front-page, coverage to the voter registration controversy. See Northern Iowan, 9/25/1970, 10/20/1970, 10/23/1970; Cedar Falls Record, 10/17/1970, 10/19/1970, 10/21/1970, 10/22/1970; Waterloo Daily Courier, 10/16/1970, 10/18/1970, 10/20/1970, 10/21/1970, 10/22/1970.

62. Northern Iowan, 10/12/1971. 
and the council appointed Williams to replace him. ${ }^{63}$ Williams was no political newcomer, however. He had represented the Fifth Ward on the city council since 1958. He and the four incumbent councilmen ran in the November election as the "Pride in our City" slate along with the incumbent city treasurer and park commissioner and the candidates for hospital trustee and riverfront commissioner.

Jon Crews was one of three candidates challenging Williams in the mayor's race. Crews, a UNI history graduate student in his mid-twenties, had lived most of his life in Cedar Falls. He had attended West Point for a year-and-a-half before returning to Cedar Falls to complete his bachelor's degree at UNI. He worked as a substitute teacher and, until June 1971, was in the army reserve. Crews was active in local Democratic Party politics and civic affairs and was one of the mobile registrars working to register students to vote on the UNI campus in fall 1970. Crews presented himself to voters as an environmentalist. As cochair of the local recycling task force, he had organized drives to collect aluminum cans during the summer of 1971. Several short newspaper stories announcing these activities gained him favorable publicity and increased his name recognition in the months before he announced his run for mayor, as did a series of letters to the editor by Crews that appeared in the Cedar Falls Record and the UNI student newspaper, the Northern Iowan ${ }^{64}$

Although a college student, there was nothing in Crews's appearance to alarm older voters. The photo of Crews in his campaign ads showed a clean-shaven young man in suit and tie with short hair neatly combed. Postelection analysis in the Waterloo Daily Courier characterized Crews's campaign style as "low keyed, not radical." ${ }^{65}$ His membership in the Jaycees and involvement in his church made him indistinguishable from many of the older candidates running for local office.

63. As a result of McKinley's resignation, voters in the November 2 election would be voting to select a mayor to finish the current term that would end December 31, 1971, and a mayor for a full term to end December 31, 1973.

64. Jon Crews, interview with Clyde Brown, 8/17/2007; Cedar Falls Record, 6/4/1971, 6/8/1971, 7/8/1971, 7/14/1971, 7/27/1971, 8/18/1971; Northern Iowan, 5/11/1971, 5/21/1971, 7/2/1971; Waterloo Daily Courier, 8/18/1971.

65. Waterloo Daily Courier, 11/3/1971. 
In his campaign, Crews did not present himself as the "students' candidate," and he made no special effort to garner student support, but he believed his candidacy "gave students a choice." ${ }^{\prime 66}$ No Crews campaign ads ran in the student newspaper, which ran few news stories about the November 2 election and none that mentioned Crews by name. ${ }^{67}$ The two Crews campaign advertisements in the Cedar Falls Record included the names of supporters, a long list of Messrs. and Mesdames. More than newspaper ads, Crews's campaign relied on yard signs, small neighborhood meetings, door-to-door canvassing, and supportive letters to the editor. Crews ran on his own, unlike some city council challengers who formed the "Independents United Party" to counter the incumbents' "Pride in our City" slate. ${ }^{68}$

The big issues in the November election involved a proposal to build a north-south freeway through Cedar Falls to relieve local traffic congestion and complaints that the current administration had used the power of appointment to perpetuate itself in office and as a result governed imperiously. Opponents of the freeway, Highway 518, charged that it would divide the city, and, as proposed, it did. A portion of the route followed Dry Run Creek through the city and then nicked the northwest corner of the UNI golf course. Crews took a stand against the freeway. In a July 27 letter to the editor, nearly a month before he formalized his candidacy, he stated unequivocally, "I stand opposed to dividing Cedar Falls by Highway 518." ${ }^{\prime \prime 9}$ That state-

66. Crews interview. The Des Moines Register, 10/31/1971, reported that "there has been no noticeable student drive to support Crews - or any other Cedar Falls candidate."

67. The lack of coverage can be explained in part by the fact that the Northern Iowan appeared only twice per week. There was more extensive coverage of the city elections in the UI and ISU student newspapers, which came out five days per week and routinely included local, state, and national news along with coverage of campus events. For the important role played by a campus newspaper in one town's politics at the time, see Charles Atkin, "The Role of the Campus Newspaper in the Youth Vote," College Press Review 13 (1974), 6-9. Atkin studied the Michigan State News's impact on the East Lansing elections of 1971 and 1972.

68. Crews interview; Cedar Falls Record, 10/15/1971, 10/20/1971.

69. Cedar Falls Record, 7/27/1971. When the Cedar Falls freeway finally opened in 1993, it ran from US 20 north to University Avenue, and was designated Iowa Highway 58. 
ment, repeated in one of his campaign ads, was not enough to win Crews the endorsement of the citizens group formed to oppose the freeway. Later, in the midst of the campaign, Crews called for exploration of all transportation alternatives, including mass transit, bike paths, and upgrading existing roads, while appealing to anti-freeway voters for their support, saying he would "study the transportation needs of our future with an anti-freeway bias." ${ }^{70}$

The other major issue in the campaign involved the charge that for almost 20 years the mayor and city council had used the power of appointment to bring political allies into office. Those appointees then had the advantage of incumbency at election time. Williams's appointment as mayor was a case in point. The city council had tapped him for the office when the previous mayor resigned in the spring, and then appointed Emory Peterman to fill the Fifth Ward council seat Williams vacated. ${ }^{71}$ One of the at-large council members running with Williams as part of the "Pride in our City" slate also was an appointee. Terry Olin took office September 1, replacing Maurice Alderman, who moved from the city council to the Cedar Falls Utilities Board of Trustees. Candidates challenging the "Pride in our City" slate denounced the "practice of self-perpetuation" that a cliquish city administration had perfected over the course of 18 years. ${ }^{72}$

Crews addressed the "self-perpetuation" charge indirectly. He called for a city government drawn from a broad spectrum of the Cedar Falls community, adding that the current administration was "made up of businessmen 'who look at things as businessmen.'" He believed that "new blood" was needed to ensure a city government that was "sensitive and responsive" to people's problems. Shouldering aside opponents to Highway 518 was the most egregious example of city government's insensitivity, but there were smaller grievances as well - cutting down trees along Pleasant Avenue for a street widening project

70. Cedar Falls Record, 10/7/1971, 10/26/1971, 10/30/1971; Waterloo Daily Courier, $10 / 25 / 1971$.

71. The previous mayor, William McKinley, had been appointed to office as well. McKinley was serving as city attorney in 1963 when he was appointed mayor. Waterloo Daily Courier, 11/1/1971.

72. Cedar Falls Record, 9/23/1971, 10/1/1971; Waterloo Daily Courier, 10/5/1971. 
over residents' objections and ignoring repeated pleas for relief from homeowners along Dry Run Creek who endured basement flooding with every heavy rain. ${ }^{73}$

Numerous letters to the editor appeared in the Cedar Falls Record urging citizens to vote for Crews. The letter writers described him as "energetic," "sharp minded," and "well educated," with "intelligence, integrity, and enthusiasm" and the "initiative, drive, and determination" the city needed. Some writers praised Crews for his promise to be a full-time mayor. Letters questioning Crews's fitness for office also appeared in the local paper. Those letters did not mention Crews by name, but the criticism of youth and inexperience made it clear that the writers were targeting Crews. One writer asked, "'Course a fella hasta start somewhere with all that book learnin' . . but mayor?" To counter the attacks on Crews's youth, some supportive letter writers made a point of describing Crews as "mature well beyond his years." A campaign ad tried to neutralize the age issue, saying Crews was "young enough to understand the problems of the youth of Cedar Falls and yet old enough to understand the responsibility of taking action on problems that affect all age groups." ${ }^{74}$

Crews won the election for the full term as mayor with 3,066 votes $(41 \%)$, besting Williams, the incumbent, and two other challengers (see table 3). In the four-person race, Crews received strong support from Fourth Ward voters (52\%) where the University of Northern Iowa was located. ${ }^{75}$ Voter turnout was 49 percent; a record 7,873 voters voted. Crews benefited from an anti-incumbent sentiment among voters. Only two members of the "Pride in our City" slate who faced challengers won their elections - Park Commissioner Eugene Fisher and Fifth Ward Councilman Peterman. Peterman, who had been appointed to city council the previous spring, was able to hold off three challengers.

73. Cedar Falls Record, 10/19/1971; Waterloo Daily Courier, 10/19/1971.

74. Cedar Falls Record, 10/15/1971, 10/16/1971, 10/19/1971, 10/20/1971, 10/26/ 1971, 10/29/1971.

75. Cedar Falls Record, 11/4/1971, 35; Waterloo Daily Courier, 11/3/1971. Crews also won the mayoral race for the unexpired term. He received 2,906 votes to 2,591 for Williams, with the other two candidates tallying 1,615 and 473 votes. See Cedar Falls Record, 11/3/1971. 


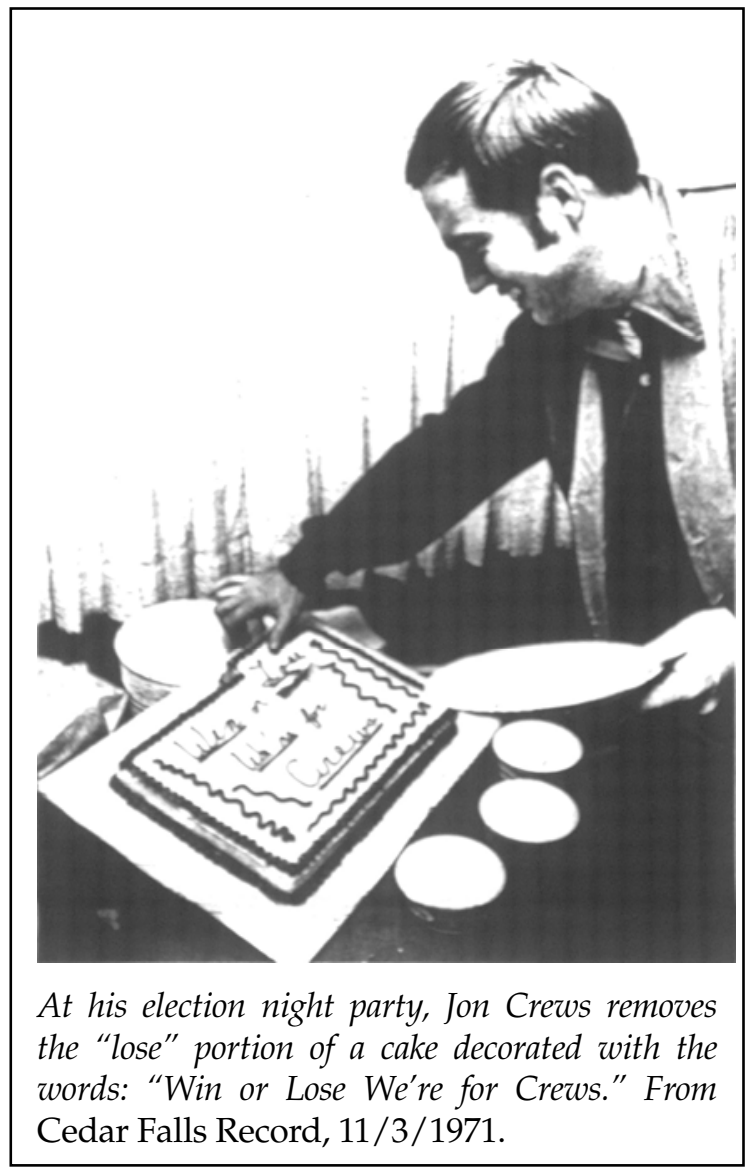

TABLE 3

ELECTORAL RESULTS OF NOVEMBER 2, 1971, CEDAR FALls MAYORAL ELECTION (FULL TERM)

BY PRECINCT AND TOTALS (STUDENT CANDIDATE NOTED BY ASTERISK; PRECINCTS WITH SUBSTANTIAL STUDENT POPULATION IN BOLD)

\begin{tabular}{lrrrrrrrrrrr}
\hline Precinct & $1-1$ & $1-2$ & $2-1$ & $\mathbf{2 - 2}$ & $3-1$ & $3-2$ & $\mathbf{4 - 1}$ & $\mathbf{4 - 2}$ & $5-1$ & $5-2$ & Totals \\
\hline Crews $^{*}$ & 151 & 240 & 199 & $\mathbf{5 0 3}$ & 225 & 398 & $\mathbf{4 1 1}$ & $\mathbf{3 9 0}$ & 331 & 218 & 3,066 \\
Drea & 56 & 131 & 85 & $\mathbf{3 2 3}$ & 209 & 207 & $\mathbf{1 7 4}$ & $\mathbf{2 0 1}$ & 172 & 185 & 1,743 \\
Sutherland & 38 & 69 & 66 & $\mathbf{6 4}$ & 37 & 91 & $\mathbf{3 8}$ & $\mathbf{2 5}$ & 37 & 38 & 503 \\
Williams & 84 & 152 & 128 & $\mathbf{2 3 9}$ & 282 & $\mathbf{2 7 3}$ & $\mathbf{1 7 9}$ & $\mathbf{1 1 5}$ & 338 & 300 & 2,090 \\
\hline
\end{tabular}

SOURCE: Office of the City Clerk, Cedar Falls, Iowa. 
Crews was one of a handful of youthful candidates who won local office in November 1971 in Iowa and across the nation. ${ }^{76}$ The election was the beginning of a long political career for Crews. Over the next three-and-a-half decades he would be elected to 11 more terms as Cedar Falls mayor, most recently in November 2007.

THE UNIVERSITY OF IOWA, Iowa's oldest public institution of higher education, was established in late February 1847, only two months after Iowa achieved statehood. Like many colleges in frontier areas, it floundered for several years, poorly funded and suffering from a dearth of qualified students. Overcoming its rocky beginnings, by the end of the nineteenth century it was home to the state's only public law school and medical school. Professional education in agriculture and veterinary medicine was left to Iowa State University in Ames. In 1970 UI enrolled more than 20,000 students, making it about the same size as ISU and more than twice the size of UNI. ${ }^{78}$

UI is located in Iowa City in southeast Iowa. In 1970 Iowa City's population numbered 47,000, with demographics that closely paralleled those of Ames (see table 1$).{ }^{79}$ Like other growing communities, Iowa City in 1971 was dealing with a tight housing market, traffic congestion, and downtown parking problems. A municipal bus system began operation in September, and planning for downtown urban renewal was under way. In addition, violent antiwar demonstrations in May 1970 and 1971 had strained relations between students and police beyond the usual irritants of alcohol, drugs, and traffic tickets.

Three of the city's five council seats were on the ballot in the November 2, 1971, Iowa City election. ${ }^{80}$ At that time all members

76. New York Times, 11/4/1971, 35; Des Moines Register, 11/3/1971, 11/4/1971; Des Moines Tribune, 11/3/1971.

77. Jon Ericson, "Crews Makes History with Re-election," Waterloo/Cedar Falls Courier Online Edition, 11/7/2007, www.wcfcourier.com/articles/2007/11/07/ news/metro.

78. Iowa City Press-Citizen, 10/1/1971.

79. U.S. Bureau of the Census, County and City Data Book, 1972, 690-701.

80. The only other item on the ballot was a bond referendum to finance the expansion of the Iowa City water treatment plant. 
of the council were elected at large, and they selected a mayor from among themselves. Fifteen candidates entered the race. Two were incumbents seeking re-election; a third incumbent decided not to run. The other 13 candidates included five students, a UI administrator, a minister, a medical doctor, a welfare recipient, a small businessman, and a presidential aspirant. According to the University of Iowa student newspaper, they made up the largest group of candidates in city history, an indication of the widespread interest in changing the direction of city government. ${ }^{81}$

Ten of the 13 challengers could be considered liberal, evidence that the impetus for change was coming from the left side of the political spectrum. In mid-summer, Democratic Party regulars began seeking three candidates who, if they won, would become the new majority on city council. At the same time, the New Party, a short-lived effort at third-party progressive politics in Iowa in the early 1970s, put forth its own threecandidate slate. This New Coalition, as it called itself, included two University of Iowa graduate students, Raymond Rohrbaugh and Joseph Savarino, and an advocate for the poor, Patricia Schmidtke. Democratic Party regulars did not believe the New Coalition candidates had the broad appeal needed to win citywide. Instead, they put together a slate of three candidates they considered more electable. That so-called Independent Citizens Slate was made up of Esther Atcherson, a Johnson County probation officer; Edgar Czarnecki, director of the UI Center for Labor and Management; and dermatologist Richard Winter. A local environmental group ranked Winter, Rohrbaugh, and Savarino most favorably while opposing the two incumbents. ${ }^{82}$

In addition to the two graduate students who were part of the New Coalition, three other students entered the race for city

81. Daily Iowan, 10/18/1971. The Iowa City Press-Citizen was a bit more circumspect, characterizing the 15 candidates as "the largest number . . . in recent memory here." Iowa City Press-Citizen, 10/16/1971.

82. Iowa City Press-Citizen, 10/8/1971. Candidates running together as a slate were not identified as such on the ballot in Iowa City or Ames. The Cedar Falls ballot did identify candidates with the name of their slate, grouped them together, and permitted straight ticket voting. In Iowa City the "slate" designation was used by candidates in advertisements and by newspaper reporters covering the election. 
council - two UI undergraduates, David Osmundson and Jerry Showman, and John Kenney, who attended the local community college. The youngest student candidate was 19; the other four were older, ranging in age from 26 to 39. Several of the student candidates were critical of the police department's handling of student demonstrations in May 1971, when, according to Osmundson, "a lot of people got unnecessarily beat on the head." Osmundson went on to call for the dismissal of Police Chief Patrick McCarney so a "more rational man" could be hired. Showman wanted city government and the police to "cultivate the respect of students in this community." Savarino criticized the present city council for not condemning "excesses on the part of law enforcement in Iowa City." Other candidates addressed the issue in softer terms, calling only for more communication or a better relationship between the university and the city. ${ }^{83}$

A primary election was held October 19 to reduce the number of candidates to six. Before the primary, the UI Student Senate endorsed Czarnecki and Winter from the Independent Citizens Slate and Rohrbaugh of the New Coalition. Rohrbaugh, a 32-year-old graduate student in the UI School of Religion, was active in antiwar activities and had taken part in fasts and civil disobedience in opposition to the Vietnam War. The Student Senate announced the endorsements in a letter sent to students who had registered to vote. ${ }^{84}$ To further publicize the endorsements, the Student Senate ran an advertisement in the student newspaper, the Daily Iowan, on the day of the primary. It consisted of a copy of the ballot with arrows pointing to the names of the endorsed candidates and asked students to vote for them if they were "TIRED of Tear Gas . . . Poor Housing . . . Being Misrepresented ... Bicycle Harassment." ${ }^{15}$

Efforts had been made early in the school year to get students on the voter rolls. When UI students went to the University

83. Daily Iowan, 6/30/1971, 8/4/1971; Iowa City Press-Citizen, 7/7/1971, 9/27/ 1971.

84. Minutes, Student Senate Meeting, 10/14/1971, Records of the UI Student Government, University of Iowa Archives, University of Iowa Libraries; Daily Iowan, 10/18/1971.

85. Daily Iowan, 10/19/1971. 


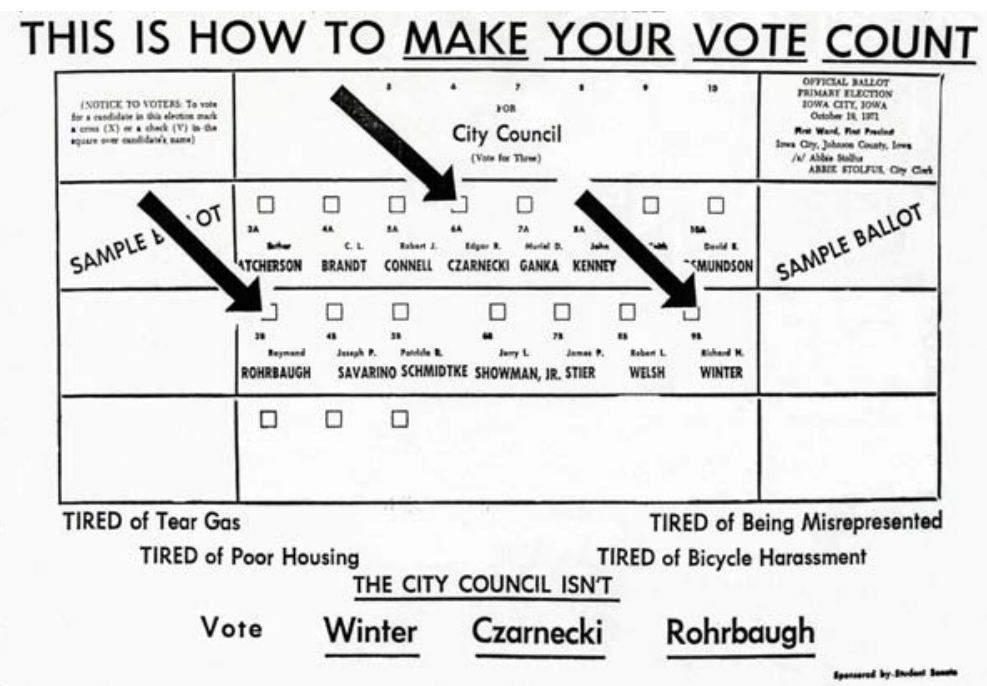

The University of Iowa Student Senate ran this ad in the student newspaper on the day of the primary election. From Daily Iowan, 10/19/1971.

Field House to sign up for fall classes, the local chapter of the League of Women Voters provided an opportunity for them to register to vote. About 1,800 students registered during the three-day event. The student newspaper weighed in as well, urging students to register to vote in a series of "flower power" illustrations on its editorial page, an editorial by Editor-in-chief Tom Walsh, and the writings of opinion page columnists. The Student Senate launched its own drive, going door-to-door in dormitories, fraternities, and sororities the week prior to the October 8 voter registration deadline for the primary election. That effort brought in about 700 new voters. Altogether, 2,500 new voters were registered in the month leading up to the primary, bringing the total number of registered voters in Iowa City to 26,000. Student voting was not without controversy in Iowa City. In phone calls to townspeople the week before the primary election, supporters of the two incumbents and conservative challenger Keith Noel raised the specter of a student takeover of city government. ${ }^{86}$

86. Daily Iowan, 9/21/1971, 9/28/1971, 10/21/1971; Iowa City Press-Citizen, 10/16/1971; Minutes, Student Senate Meetings, 9/21/1971, 9/28/1971, Rec- 
The primary election produced a record voter turnout 7,511 , about 29 percent of eligible Iowa City voters. ${ }^{87}$ Voters were able to vote for three candidates, with the top six vote getters winning places on the general election ballot. The two incumbents in the race, Robert Connell and C. L. Brandt, received the most support in the primary election; Connell garnered nearly 3,400 votes and Brandt almost 3,000. Both were small business owners. Connell was considered the most conservative member of city council. The Iowa City Press-Citizen tagged Brandt a moderate, and he seemed to agree. He told a student editor from the Daily Iowan that university students, or the "west side of Clinton Street," considered him too conservative while townspeople, whom he called the "east side of Clinton Street," considered him "too damn liberal." ${ }^{88}$ Other primary winners included Keith Noel, a small business owner, and minister Robert Welsh. Edgar Czarnecki and Richard Winter, the two members of the Independent Citizens Slate endorsed by the UI Student Senate, also won places on the general election ballot. They did well in the First and Second wards where large numbers of students lived, but Czarnecki's vote total was 1,300 behind Connell's, and Winter received only about half the votes Connell did. None of the student candidates survived the primary election. ${ }^{89}$

ords of the UI Student Government. Brad Haddy, chair of the UI Student Senate's Legislative Action Committee, reported that the voter registration effort garnered 4,000 voter registrations. That number is considerably higher than the 2,500 new voters reported in a front-page story in the Iowa City PressCitizen. It is possible that Haddy's number included voters who lived somewhere in Johnson County other than Iowa City and individuals who were not new voters, but who had moved since the last election and needed to register at their new address. In addition, two mobile registrars turned in voter registration cards after the deadline; as a result about 250 individuals were unable to vote in the primary. Minutes, Student Senate Meeting, 10/12/1971, Records of the UI Student Government; Iowa City Press-Citizen, 10/18/1971; Cedar Rapids Gazette, 10/20/1971.

87. Iowa City Press-Citizen, 10/20/1971.

88. Daily Iowan, 10/25/1971. Clinton Street is roughly the eastern boundary of the UI campus, with the downtown business district on one side and major university buildings, such as Old Capitol, Schaeffer Hall, and Macbride Hall on the other side.

89. Iowa City Press-Citizen, 10/20/1971; Daily Iowan, 10/20/1971. 
Given the strong showing by the incumbents and the elimination of student candidates and the entire New Coalition slate, liberal forces hoping to change the direction of city government had their work cut out for them in the two weeks between the primary and general elections. Three liberal candidates remained in the race: Czarnecki, Winter, and Welsh. Welsh, pastor of the First Christian Church and former chair of the city's Housing Commission, had long been interested in expanding housing opportunities for low-income Iowa City residents. The New Coalition's Rohrbaugh endorsed Welsh after his own defeat in the primary..$^{90}$

The six primary winners used the Daily Iowan to court student voters before the general election. They all placed advertisements in the student newspaper, whereas only the Independent Citizens Slate had done so before the primary. Even Brandt, Connell, and Noel, whose supporters were not above rousing townspeople by warning of a student takeover of city government, ran ads in the student newspaper. Brandt's ad included the candidate's observation that "there are as many stupid Iowa Citians as there are stupid students," a frank, if awkward, attempt to answer those who considered students less qualified to vote than other voters. An ad for Noel in the Iowa City PressCitizen could easily have appeared in the Daily Iowan. It showed Noel outside a university building doing his part to bridge "the generation gap" by talking to a long-haired male student and a female student in a fringed poncho. All but one of the candidate advertisements in the Daily Iowan appeared on Election Day. ${ }^{91}$

The student newspaper provided better coverage of the city council race after the primary than it had beforehand. Before the primary, only three candidate profiles ran in the Daily Iowan, and those all appeared during the summer when many UI students were not in Iowa City. The other 12 candidates were identified briefly in a front-page story on primary election day or in earlier stories that dealt with other election issues, such as the voter registration deadline or location of polling places, and did

90. Welsh campaigned as a moderate while recognizing that some voters would see him as a "radical liberal" and "some liberal students" would tag him an "old conservative." Daily Iowan, 10/18/1971, 10/28/1971, 11/1/1971.

91. Daily Iowan, 11/2/1971; Iowa City Press-Citizen, 10/27/1971. 
little more than list candidates' names. For the general election, however, the Daily Iowan ran extended profiles of the six candidates, giving information on their background and the issues that were important to them, although discussion of issues was done only in the most general terms. All of the candidates made either a direct or indirect pitch for student votes, promising variously to represent student interests or appoint students to city committees and commissions, or claiming to get along well with students. Fearing that the newspaper would lose its taxexempt status if it endorsed political candidates, the Student Publications Board, which was responsible for overseeing student publications, ordered the Daily Iowan staff not to do so. ${ }^{92}$

The UI Student Senate endorsed Czarnecki and Winter in the general election, two of the three candidates it had supported in the primary. In what it termed "a hard nosed political consideration," the senate, led by President Ted Politis and VicePresident Mike Vance, urged students to cast only two votes, not the three votes allowed. As the Student Senate explained to students in a Daily Iowan advertisement, Czarnecki and Winter were the "only two candidates running [who] really merit your vote. . . . we will not be throwing away a third vote, but we would be casting one and a half votes for each." The two-vote strategy proved controversial. A group calling itself "Students for a Better Iowa City" told students, "Don't disenfranchise yourself," and urged them to cast three votes - for Czarnecki, Winter, and Welsh. The Welsh campaign ran a similar ad, advising students to "give one of your votes to Bob Welsh" in order to "make your FULL impact felt."

A record 10,325 voters took part in the Iowa City election on November 2, 1971, topping the previous high by nearly 2,500 votes. Incumbents Brandt and Connell won re-election along with challenger Czarnecki. Czarnecki did very well in precincts

92. The Student Publications Board took action after editorial page editor D. M. Blake endorsed two candidates in the September 13 Iowa City school board election. Blake protested the board's order in an editorial titled "Shut My Mouth!" days before the November 2 election. Daily Iowan, 9/10/1971, 10/29/ 1971, 11/4/1971.

93. Minutes, Student Senate Meeting, 10/26/1971, Records of the UI Student Government; Daily Iowan, 11/2/1971. 
TABLE 4

ELECTORAL RESUlTS OF NOVEMBER 2, 1971, IOWA CITY MUNICIPAL ELECTION BY PRECINCT AND TOTALS (PRECINCTS WITH SUBSTANTIAL STUDENT POPULATION IN BOLD)

\begin{tabular}{lcccccc}
\hline Precinct & Brandt & Connell & Czarnecki & Noel & Welsh & Winter \\
\hline $\mathbf{1 - 1}$ & $\mathbf{5 1}$ & $\mathbf{9 7}$ & $\mathbf{2 6 0}$ & $\mathbf{8 7}$ & $\mathbf{1 1 3}$ & $\mathbf{2 6 0}$ \\
$\mathbf{1 - 2}$ & $\mathbf{1 0 8}$ & $\mathbf{8 0}$ & $\mathbf{2 5 9}$ & $\mathbf{6 2}$ & $\mathbf{1 3 6}$ & $\mathbf{2 3 8}$ \\
$\mathbf{1 - 3}$ & 238 & 239 & 258 & 214 & 245 & 248 \\
$\mathbf{1 - 4}$ & $\mathbf{1 4 6}$ & $\mathbf{1 2 0}$ & $\mathbf{3 8 9}$ & $\mathbf{1 0 2}$ & $\mathbf{2 6 9}$ & $\mathbf{3 4 3}$ \\
$\mathbf{2 - 1}$ & $\mathbf{1 7 7}$ & $\mathbf{1 7 2}$ & $\mathbf{4 2 9}$ & $\mathbf{1 5 7}$ & $\mathbf{2 5 1}$ & $\mathbf{4 0 4}$ \\
$\mathbf{2 - 2}$ & $\mathbf{3 1 8}$ & $\mathbf{2 2 1}$ & $\mathbf{4 0 2}$ & $\mathbf{1 9 7}$ & $\mathbf{3 5 4}$ & $\mathbf{3 8 2}$ \\
$\mathbf{2}-3$ & 309 & 189 & 183 & 168 & 271 & 163 \\
$3-1$ & 245 & 253 & 177 & 210 & 190 & 130 \\
$3-2$ & 185 & 262 & 120 & 258 & 124 & 86 \\
$\mathbf{4 - 1}$ & $\mathbf{1 7 0}$ & $\mathbf{2 1 9}$ & $\mathbf{2 7 1}$ & $\mathbf{2 1 2}$ & $\mathbf{1 7 8}$ & $\mathbf{2 4 9}$ \\
$\mathbf{4 - 2}$ & $\mathbf{1 9 8}$ & $\mathbf{1 9 3}$ & $\mathbf{2 8 7}$ & $\mathbf{1 6 9}$ & $\mathbf{1 9 7}$ & $\mathbf{2 6 2}$ \\
$4-3$ & 376 & 384 & 184 & 308 & 279 & 126 \\
$4-4$ & 246 & 249 & 137 & 200 & 215 & 104 \\
$5-1$ & 204 & 248 & 241 & 219 & 159 & 225 \\
$5-2$ & 222 & 287 & 148 & 276 & 188 & 123 \\
$5-3$ & 217 & 273 & 177 & 254 & 173 & 131 \\
$5-4$ & 415 & 450 & 317 & 412 & 324 & 256 \\
$5-5$ & 230 & 312 & 134 & 285 & 155 & 89 \\
$5-6$ & 165 & 162 & 117 & 138 & 115 & 93 \\
$5-7$ & 695 & 558 & 369 & 432 & 553 & 292 \\
\hline Totals & 4,915 & 4,968 & 4,859 & 4,360 & 4,489 & 4,204 \\
\hline
\end{tabular}

SOURCE: Office of the City Clerk, Iowa City, Iowa.

in the First, Second, and Fourth wards, where large numbers of university students resided (see table 4 ). "The youth vote was critical," Czarnecki told the Cedar Rapids Gazette. Even Brandt and Connell, who were not endorsed by the UI Student Senate, expressed admiration for the students' efforts. They, too, believed that student voters played an important role in Czarnecki's victory. "You can't help but be impressed with the reports that the student senate got out 2,700 votes," said Connell. Brandt called the 67 percent student turnout "fantastic," adding, "maybe the youth of today are teaching their elders something about the use of the democratic process." ${ }^{94}$

94. Cedar Rapids Gazette, 11/4/1971. 
Welsh and Winter also did well with students, but did not pick up enough support from other segments of the population to bring them victory. ${ }^{95}$ In this regard, Czarnecki was helped by his involvement in the local Democratic Party and the Iowa City Chapter of Americans for Democratic Action, his ties to area labor unions, and support from blue collar workers. In postelection analysis, an editorial in the Iowa City Press-Citizen said that Czarnecki was part of a "liberal element drawing much of its support from within the university community but extending beyond" that represented a "new force" in city government. ${ }^{96}$

Within days of the November 2 election, the UI Student Senate announced plans for a petition drive to put a referendum before voters to change Iowa City's government from at-large representation to one that combined ward and citywide representation. ${ }^{97}$ UI senators believed that student candidates would have done better at the polls and student concerns would be more likely to be listened to if council members were elected from wards, especially since students most likely would be the majority in one or two wards. Several candidates, including Czarnecki, had come out in favor of ward representation during the fall campaign, and the League of Women Voters had asked candidates to address the issue for candidate profiles that appeared in the October 30 Iowa City Press-Citizen, but the matter was not a factor in the election. ${ }^{98}$ In 1973 Iowa City voters amended the city charter to increase the city council from five to seven members and change the way council members were elected, opting for a combination of at-large and modified district representation. The charter changes implemented at that time remain in effect today. ${ }^{99}$

95. Winter ran well ahead of Welsh in the student precincts. A Cedar Rapids Gazette analysis estimated that more than 3,000 voters, about one-third of all voters, followed the Student Senate's recommended strategy of casting two, rather than three votes. Cedar Rapids Gazette, 11/4/1971.

96. Iowa City Press-Citizen, 7/29/1971, 10/8/1971, 10/15/1971, 11/3/1971; Cedar Rapids Gazette, 11/3/1971, 11/4/1971.

97. Minutes, Student Senate Meeting, 11/9/1971, Records of the UI Student Government.

98. Iowa City Press-Citizen, 10/7/1971, 10/11/1971, 10/12/1971, 10/30/1971, 11/5/1971.

99. Four of the seven city council members are elected at large and are referred to as "council members at-large." Each of the other three represent one of three 
STUDENTS AT ISU, UNI, AND UI took advantage of the opportunity provided by the Twenty-sixth Amendment's expansion of the electorate to affect local politics. The November $1971 \mathrm{mu}-$ nicipal elections were in essence the first test of the newly enfranchised cohort's electoral power in Iowa. The extent of those efforts and the results achieved varied across the three towns, with some degree of success achieved in all three locations. Several factors contributed to the relative success of the three efforts in Ames, Cedar Falls, and Iowa City (see table 5). The factors include the electoral context, especially the election system and rules in place in each city, the effort to register the newly enfranchised 18- to 20-year olds in their college communities, the candidates who ran for office, the issues that motivated student activists, and, perhaps most important, the strength of the youth organizations that developed to contest the local elections.

The electoral rules in place aided student efforts in Ames and Cedar Falls but were detrimental to the Iowa City campaign. Working against proponents of student power in Iowa City were the requirements of an at-large election and the use of a traditional primary election. In all three cities, students were part of a larger political system that included other townspeople. Students, for the most part, resided in campus dormitories or nearby housing. At-large voting systems diluted the students' numbers, and ward systems accentuated their concentrated numbers. The ward system was a major factor in Russell Pounds's victory in Ames. In Iowa City the five student candidates in a crowded field of 15 candidates failed to get past the primary election stage where typically fewer voters participate. Important for Jon Crews's election as mayor in Cedar Falls was the lack of a majority winner requirement; he was elected to the full term office with only slightly more than 40 percent of the vote. If Crews had been running in Ames, for instance, he would have been required to participate in a runoff election against the second place vote getter. Election rules, as mundane as they appear, have a major effect in determining who wins and loses local electoral contests; they certainly did in 1971.

districts into which the city is divided. They, too, are elected at-large, but only after being nominated by voters in their respective districts. Iowa City PressCitizen, 11/16/1973; City of Iowa City, "Council Candidates," www.icgov.org. 
TABLE 5

FACTORS AFFECTING THE SUCCESS OF THE STUDENT VOTE IN THE MuNICIPAL ELECTIONS IN AMES, CEDAR FALLS, AND IOWA CITY IN 1971

(CONDITIONS ADVANTAGING STUDENTS IN BOLD, FACTORS DISADVANTAGING STUDENTS IN ITALICS, AND NEUTRAL FACTORS IN REGULAR FONT)

\begin{tabular}{|c|c|c|c|}
\hline Factors & Ames & Cedar Falls & Iowa City \\
\hline \multicolumn{4}{|l|}{ Election Rules } \\
\hline $\begin{array}{l}\text { "Winner" rule for } \\
\text { general election }\end{array}$ & Majority & Plurality & $\begin{array}{l}3 X \text { first-past-the } \\
\text { wire }\end{array}$ \\
\hline Primary Election & $\begin{array}{l}\text { Run-off, if } \\
\text { needed }\end{array}$ & No & $\begin{array}{l}\text { Yes, pick 3, } 6 \mathrm{X} \\
\text { first-past-the wire }\end{array}$ \\
\hline $\begin{array}{l}\text { Representation } \\
\text { system }\end{array}$ & $\begin{array}{l}\text { Mixed: ward } \\
\text { and at-large }\end{array}$ & $\begin{array}{l}\text { Mixed: ward } \\
\text { and at-large }\end{array}$ & At-large \\
\hline Partisan ballot & No & $\begin{array}{l}\text { No, but slate des- } \\
\text { ignation allowed }\end{array}$ & No \\
\hline $\begin{array}{l}\text { Determination of } \\
\text { mayor }\end{array}$ & At-large election & At-large election & $\begin{array}{l}\text { Elected by city } \\
\text { council }\end{array}$ \\
\hline \multicolumn{4}{|l|}{ Registration } \\
\hline Cut-off date & $\begin{array}{l}\text { October } 23 \text { for } \\
\text { general election }\end{array}$ & $\begin{array}{l}\text { October } 23 \text { for } \\
\text { general election }\end{array}$ & $\begin{array}{l}\text { October } 8 \text { for } \\
\text { primary election } \\
\text { \& October } 23 \text { for } \\
\text { general election }\end{array}$ \\
\hline $\begin{array}{l}\text { Election officials } \\
\text { authorized use of } \\
\text { mobile registrars }\end{array}$ & Yes; cooperative & No; uncooperative & Yes; cooperative \\
\hline \multicolumn{4}{|l|}{ Candidates } \\
\hline $\begin{array}{l}\text { Student } \\
\text { candidate(s) }\end{array}$ & No & $\begin{array}{l}\text { Yes (1 mayoral } \\
\text { candidate) }\end{array}$ & $\begin{array}{l}\text { Yes ( } 5 \text { city coun- } \\
\text { cil candidates) }\end{array}$ \\
\hline $\begin{array}{l}\text { Student-endorsed } \\
\text { candidates }\end{array}$ & Yes & No & Yes \\
\hline \multicolumn{4}{|l|}{ Issues } \\
\hline Campaign issues & $\begin{array}{l}\text { City Attorney's } \\
\text { retention, police- } \\
\text { student commu- } \\
\text { nity relations, un- } \\
\text { responsiveness } \\
\text { of city officials }\end{array}$ & $\begin{array}{l}\text { Proposed high- } \\
\text { way, cronyism in } \\
\text { appointments to } \\
\text { city council }\end{array}$ & $\begin{array}{l}\text { Police-student } \\
\text { community rela- } \\
\text { tions in the pri- } \\
\text { mary election; } \\
\text { little specific in } \\
\text { the general elec- } \\
\text { tion }\end{array}$ \\
\hline $\begin{array}{l}\text { Antiwar protest } \\
\text { grievances } \\
\text { against social } \\
\text { control agents }\end{array}$ & $\begin{array}{l}\text { Yes for general } \\
\text { election: May } \\
1970 \text { protests }\end{array}$ & No & $\begin{array}{l}\text { Yes for primary } \\
\text { election: } 1970 \\
\text { and } 1971 \text { pro- } \\
\text { tests }\end{array}$ \\
\hline
\end{tabular}




\begin{tabular}{|c|c|c|c|}
\hline Factors & Ames & Cedar Falls & Iowa City \\
\hline \multicolumn{4}{|l|}{ Organization } \\
\hline $\begin{array}{l}\text { Voter registration } \\
\text { organizations }\end{array}$ & $\begin{array}{l}\text { Register for } \\
\text { Peace, Coalition } \\
\text { for Responsive } \\
\text { City Govern- } \\
\text { ment, university } \\
\text { student govern- } \\
\text { ment, League of } \\
\text { Women Voters }\end{array}$ & $\begin{array}{l}\text { University stu- } \\
\text { dent govern- } \\
\text { ment, City } \\
\text { Clerk's branch } \\
\text { office, Register } \\
\text { for Peace, Young } \\
\text { Democrats }\end{array}$ & $\begin{array}{l}\text { League of } \\
\text { Women Voters, } \\
\text { university stu- } \\
\text { dent govern- } \\
\text { ment }\end{array}$ \\
\hline $\begin{array}{l}\text { Approximate } \\
\text { Number of Stu- } \\
\text { dents Registered }\end{array}$ & $\begin{array}{l}3,125 \text { by general } \\
\text { election }\end{array}$ & $\begin{array}{l}1,000 \text { by general } \\
\text { election }\end{array}$ & $\begin{array}{l}2,500 \text { by pri- } \\
\text { mary election }\end{array}$ \\
\hline $\begin{array}{l}\text { Student-based, } \\
\text { non-candidate- } \\
\text { centered campaign } \\
\text { organization }\end{array}$ & $\begin{array}{l}\text { Yes, Coalition } \\
\text { for Responsive } \\
\text { City Govern- } \\
\text { ment }\end{array}$ & No & $\begin{array}{l}\text { No, but activity } \\
\text { by local New } \\
\text { Party \& local } \\
\text { Democratic } \\
\text { Party }\end{array}$ \\
\hline $\begin{array}{l}\text { Student-based, } \\
\text { non-candidate- } \\
\text { centered GOTV } \\
\text { effort }\end{array}$ & $\begin{array}{l}\text { Yes, Coalition } \\
\text { for Responsive } \\
\text { City Govern- } \\
\text { ment }\end{array}$ & No & No \\
\hline $\begin{array}{l}\text { Unified student } \\
\text { activists/elites }\end{array}$ & $\begin{array}{l}\text { Yes, Coalition } \\
\text { for Responsive } \\
\text { City Govern- } \\
\text { ment }\end{array}$ & Not a factor & $\begin{array}{l}\text { No, including } \\
\text { separate slates by } \\
\text { New Party and } \\
\text { Democratic Party, } \\
\text { and endorsements } \\
\text { by other groups }\end{array}$ \\
\hline
\end{tabular}

SOURCE: Authors' analysis.

Registration law is a special category of American election rules. Practical political experience and political science research has shown that registering to vote is the single greatest hindrance to individual voter participation. Student organizers faced both the opportunity and challenge of registering thousands of their peers in a very short time. Again, the situations varied in the three towns. Organizers in Ames had the greatest amount of time to work on the task of registering students because their classes started a week earlier than UNI and UI. ${ }^{100}$ More important in this regard was the fact that Iowa City activists had two fewer weeks than their UNI counterparts and three fewer

100. Student organizers at ISU interested in registering students benefited from hosting the statewide Register for Peace convention in the sense that it "jump started" their efforts. 
weeks than at ISU because of the October 8 voter registration deadline for the primary election. Unlike Ames and Iowa City, student organizers in Cedar Falls had to deal with a less than fully cooperative city clerk when it came to appointing mobile registrars and allowing them full latitude to function so as to maximize the number of student registrants. Even so, impressive numbers of students were signed up to vote in all three communities.

The candidacy of students for city council played out differently in the three cities. Students were most active in this regard in Iowa City, where five student candidates were forthcoming. The large number of candidates probably divided the student vote, preventing any of the five from surviving the primary. In Cedar Falls, a graduate student who had worked actively in the past to register college students ran for city office without calling much attention to his status as a student. Undoubtedly, he felt that emphasizing that characteristic would harm his chances with other constituencies in Cedar Falls. At ISU, student organizers made a conscious choice not to run student candidates, but instead to recruit like-minded older members of the Ames community to run for each office deemed winnable on Election Day. The strategy of endorsing a slate of non-student candidates was done only in Ames and proved very successful.

The difference between winning and losing an election often hinges on the strength of political mobilization organizations working at the grassroots level. Besides registering voters before an election, such organizations contact prospective voters to provide information (voting cues) and urge support for endorsed candidates, identify the voting intention of prospective voters, and remind prospective voters leaning toward their favored candidates to vote on Election Day. Candidate organizations and political parties often perform these functions. Here the focus is on non-candidate and non-party organizations and whether they played a significant role in the three city elections.

Organizations such as the three university student governments and the League of Women Voters in all three schools and communities registered students. Only one campus organization, however - the Coalition for Responsive City Government in Ames - completed the other tasks involved in a full political 
mobilization effort. The CRCG endorsed a slate of candidates, contacted registered student voters to provide them with information about CRCG and its endorsed candidates, delivered reminders to potential voters the day before the election, monitored voter participation by means of poll watchers on Election Day, and conducted a voter contact effort on Election Day to urge students who had not yet voted to do so before the polls closed. It is clear from the record that the CRCG's efforts were a major reason why the student-endorsed slate of candidates won election to the Ames City Council. That was not the case in Iowa City or Cedar Falls, where comparable organizations did not exist.

Even more problematic in terms of a unified student vote, in Iowa City during the primary campaign rival slates of candidates endorsed by the New Party, the county Democratic Party, environmentalists, and the student government all competed for the support of young voters. A confusing picture of endorsements would have confronted a student looking for guidance on whom to support (see table 6). Nor was there a unified message in Iowa City's general election. In contrast, in Ames student leaders formed a broad-based campus coalition that delivered a united message: "We all want you to vote for Koerber, Pounds, Calhoun, and Lane!" In the absence of dissenting voices, the CRCG was able to deliver the student vote for its candidates. Such a unified effort backed by an organization with the capacity to deliver votes was noticeably missing in Iowa City, making it harder for candidates sympathetic to student concerns to be elected.

Political mobilizing is hard work. Political scientists do not know exactly why some people choose to be political activists. It is reasonable to conclude that there was a generalized belief across the board in the minds of political mobilizers that university students' political views were more progressive and liberal than those of the adult voting population of the three towns. ISU, UNI, and UI student activists all complained about the operation of city hall and called for more responsive and more representative governments. In addition, in Ames and Iowa City (at least during the primary contest) there were specific complaints related to the steps local officials had taken to control 
TABLE 6

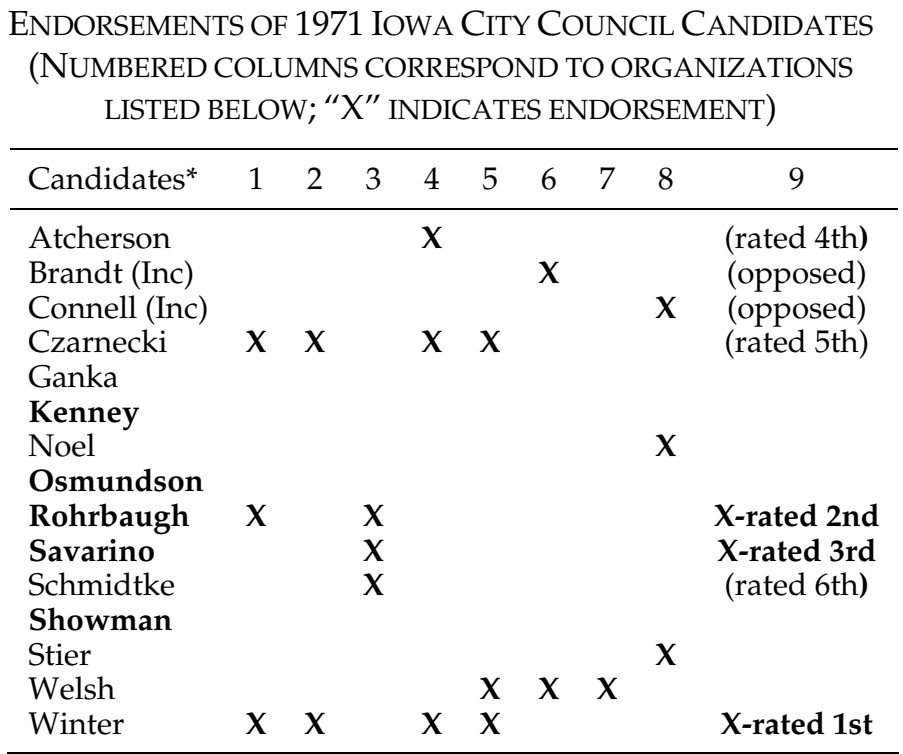

*College Students in bold

$1=$ UI Student Senate (Primary Election)

$2=$ UI Student Senate (General Election)

$3=$ New Coalition [New Party] (Primary Election)

$4=$ Independent Citizens Slate [Democrats] (Primary Election)

$5=$ Students for a Better Iowa City (General Election)

6=Iowa City Press Citizen (Primary and General Elections)

7=Ray Rohrbaugh [Primary Election Candidate] (General Election)

$8=$ Johnson County Property Taxpayers Association

9=Citizens for Environmental Action (Primary Election)

SOURCE: Authors' data.

student protests against the Vietnam War. Objections to the behavior of law enforcement officials became the central focus of the coalition of students who organized and supported the CRCG in Ames. In Iowa City, during the primary, most of the student candidates and some other candidates voiced concern about the police response to the May 1971 protests, but that issue seemed to disappear by the time of the general election.

The youth vote in the three college towns had a significant impact on the city elections in 1971. It was the deciding factor in the election of two city councilors and boosted the political prestige of a third in Ames. In Iowa City, it contributed to the victory of one city council member while coming close, but fail- 
ing, to get two others over the top. And in Cedar Falls, a fellow student was elected convincingly to the highest city office. In politics, where "you win some, you lose some," the student vote passed its first test in a fairly impressive fashion.

Despite some initial indications of student power at the ballot box in 1971, such as those documented in this article, Allard Lowenstein's ambitious goal of a bipartisan youth movement capable of affecting the 1972 presidential election was not achieved. From 1972 to 2006, the youth vote did not have a significant impact on national elections. Students of political behavior have noted the failure of 18- to 20-year-olds as a group to utilize the franchise fully. Young voters are still less likely to vote than any other age cohort in America. (The situation is not as bad for college students, who are twice as likely to vote as young citizens without college experience.) For congressional elections, the downward slide that began in 1974 doggedly persists; for presidential elections, the three decade-long decline reversed direction dramatically in 2004 and improved slightly in 2008. ${ }^{101}$

But national politics is not typically where student voters can have a substantial impact; local politics is where their concentrated numbers give them an advantage. Reliable figures by demographic characteristics, such as age cohort, for local elections in the United States do not exist. However, it is a sure bet, given the low levels of participation by all age groups in such elections, that young people are even less likely to vote in city

101. Self-reported voter turnout based on eligible voting age population for 18to 20 -year-olds in congressional elections is as follows: $20.8 \%$ in $1974,20.1 \%$ in $1978,19.8 \%$ in $1982,18.6 \%$ in $1986,18.4 \%$ in $1990,16.5 \%$ in $1994,13.5 \%$ in 1998 , $15.1 \%$ in 2002 , and $17.1 \%$ in 2006 , for an average of $17.8 \%$. For all voting-age citizens, voter turnout averaged $44.7 \%$ in those nine congressional elections. The data for 18- to 20-year-old turnout in presidential elections is as follows: $48.3 \%$ in $1972,38.0 \%$ in $1976,35.7 \%$ in $1980,36.7 \%$ in $1984,33.2 \%$ in $1988,38.5 \%$ in $1992,31.2 \%$ in $1996,28.4 \%$ in $2000,41.0 \%$ in 2004 , and $44.1 \%$ in 2008 , for an average of $37.5 \%$. For all age groups, voter turnout averaged $59.1 \%$ for the ten elections. The "youth vote" broadly defined affected the 2008 presidential election by marginally increasing voter turnout over 2004, and, more importantly, by voting 2-to-1 for Barack Obama over John McCain. U.S. Bureau of the Census, "Voting-Age Population, Percent Reporting Registered and Voted," Statistical Abstract of the United States (Washington, DC, various years); U.S. Bureau of the Census, "Voting and Registration in the Election of November 2008," table 1, www.census.gov/population/www/socdemo/voting/cps2008.html; and elections.nytimes.com/2008/results/president/exit-polls.html. 
elections than they do in national elections. But student voters in Ames, Cedar Falls, and Iowa City, demonstrated in 1971 that this does not have to be the case. For anyone who believes in the potential of student voting as a determinative force in local politics, Iowa in 1971 provided important lessons on how to do it. 